\title{
RESEARCH
}

Open Access

\section{Microbial growth and volatile organic compound (VOC) emissions from carpet and drywall under elevated relative humidity conditions}

Sarah R. Haines ${ }^{1}$ (D, Emma C. Hall², Katarzyna Marciniak ${ }^{3}$, Pawel K. Misztal ${ }^{2}$, Allen H. Goldstein ${ }^{4}$, Rachel I. Adams $5^{5}$ and Karen C. Dannemiller $6,7,8,9^{*}$

\begin{abstract}
Background: Microbes can grow in indoor environments if moisture is available, and we need an improved understanding of how this growth contributes to emissions of microbial volatile organic compounds (mVOCs). The goal of this study was to measure how moisture levels, building material type, collection site, and microbial species composition impact microbial growth and emissions of mVOCs. We subjected two common building materials, drywall, and carpet, to treatments with varying moisture availability and measured microbial communities and mVOC emissions.

Results: Fungal growth occurred in samples at $>75 \%$ equilibrium relative humidity (ERH) for carpet with dust and $>85 \%$ ERH for inoculated painted drywall. In addition to incubated relative humidity level, dust sample collection site (adonis $p=0.001$ ) and material type (drywall, carpet, adonis $p=0.001$ ) drove fungal and bacterial species composition. Increased relative humidity was associated with decreased microbial species diversity in samples of carpet with dust (adonis $p=0.005$ ). Abundant volatile organic compounds (VOCs) that accounted for $>1 \%$ emissions were likely released from building materials and the dust itself. However, certain mVOCs were associated with microbial growth from carpet with dust such as $\mathrm{C}_{10} \mathrm{H}_{16} \mathrm{H}^{+}$(monoterpenes) and $\mathrm{C}_{2} \mathrm{H}_{6} \mathrm{SH}^{+}$(dimethyl sulfide and ethanethiol). $\mathrm{CO}_{2}$ production from samples of carpet with dust at $95 \% \mathrm{ERH}$ averaged $5.92 \mathrm{mg} \mathrm{hr}^{-1} \mathrm{~kg}^{-1}$, while the average for carpet without dust at 95\% ERH was $2.55 \mathrm{mg} \mathrm{hr}^{-1} \mathrm{~kg}^{-1}$.

Conclusion: Microbial growth and $\mathrm{mVOC}$ emissions occur at lower relative humidity in carpet and floor dust compared to drywall, which has important implications for human exposure. Even under elevated relative humidity conditions, the VOC emissions profile is dominated by non-microbial VOCs, although potential mVOCs may dominate odor production.
\end{abstract}

Keywords: Microbiome, Chemistry, Built environment, Carpet, Dust, VOC

\footnotetext{
* Correspondence: Dannemiller.70@osu.edu

${ }^{6}$ Department of Civil, Environmental \& Geodetic Engineering, College of Engineering, Ohio State University, Columbus, OH 43210, USA

${ }^{7}$ Division of Environmental Health Sciences, College of Public Health, Ohio State University, Columbus, OH 43210, USA

Full list of author information is available at the end of the article
}

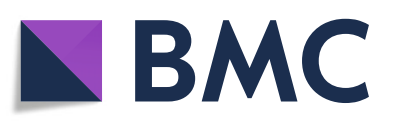

(- The Author(s). 2021, corrected publication 2021. Open Access This article is licensed under a Creative Commons Attribution 4.0 International License, which permits use, sharing, adaptation, distribution and reproduction in any medium or format, as long as you give appropriate credit to the original author(s) and the source, provide a link to the Creative Commons licence, and indicate if changes were made. The images or other third party material in this article are included in the article's Creative Commons licence, unless indicated otherwise in a credit line to the material. If material is not included in the article's Creative Commons licence and your intended use is not permitted by statutory regulation or exceeds the permitted use, you will need to obtain permission directly from the copyright holder. To view a copy of this licence, visit http://creativecommons.org/ licenses/by/4.0/. The Creative Commons Public Domain Dedication waiver (http://creativecommons.org/publicdomain/zero/1. 0/) applies to the data made available in this article, unless otherwise stated in a credit line to the data. 


\section{Background}

People spend the majority of their time indoors [1] where they are exposed to a variety of biological and abiotic contaminants. Microbial growth and moldy odors in indoor environments are associated with harmful human health effects [2-5] such as the development of asthma, wheezing and reduced lung function [6-9]. However, the causative agent(s) for these harmful health effects remains unclear [10]. The agent(s) may be a component of microorganisms or the microbial volatile organic compounds (mVOCs) microorganisms release as part of the primary and secondary metabolic processes $[11,12]$.

Moisture is the critical limiting factor to mold growth indoors [13, 14]. The US Environmental Protection Agency (EPA) recommends that homes maintain a relative humidity lower than $60 \%$, and ideally between 30 $50 \%$ relative humidity [15]. However, the relative humidity of indoor air does not stay constant and varies with outdoor humidity, occupant density, indoor activities, the air exchange rate, and moisture buffering materials inside [16, 17].

Microbes grow in carpet dust and gypsum drywall under elevated $(>80 \%)$ relative humidity conditions [1820]. Microbial growth in both these substrates may be sustained for an extended period of time even after the relative humidity in the air has decreased [19, 21]. Drywall and carpet dust differ in moisture uptake. Drywall is quick to absorb moisture and slow to dry [20, 22]. On the other hand, water uptake in dust is more nuanced, as dust mixtures constitute many different particles that may uptake water differently [23-25]. Therefore, the relative humidity in the surrounding air may be sufficient to support fungal growth in building materials, although the specifics of the process likely depend on the substrate.

Moisture may also impact the release of volatile organic compounds (VOCs) of both biological and abiotic origin. Many compounds have been identified as mVOCs resulting from microbial growth on substrates such as drywall and carpet [11]. The specific VOCs produced by microbes can change and are impacted by substrate [26, 27], microbial species type [28, 29] and other parameters (e.g. temperature, $\mathrm{pH}$ ) which can vary based on the geographic location [11, 30-32]. Geographic location is known to influence the microbiome of the built environment due to differences in outdoor microbial communities impacted by atmosphere, land type, climate and human occupant factors [33, 34]. Different homes contain different microbial communities [19] and housing characteristics such as number of occupants, presence of pets, urbanization level, air conditioner usage among others influence indoor taxonomy [35].

Certain VOCs, such as 1-octen-3-ol and 2-ethyl-1-hexanol, are also known to have both microbial and non- microbial sources [26]. Carpet releases hundreds of VOCs, acting as a primary source of VOCs in the indoor environment [36-40]. Household moisture may also impact the release of VOCs from indoor materials independent of microorganisms [41, 42] because high relative humidity conditions cause polar compounds to be desorbed quickly [43, 44]. For example, the emissions rate of toluene, n-butyl acetate, ethylbenzene and m,pxylene from wooden floors have been observed to increase when the relative humidity was raised from 50 to $80 \%$ [42]. However, we need to better understand how material type and sample location influence microbial growth and mVOCs in different building materials under different relative humidity conditions to ultimately elucidate the impact on the chemistry within a damp home.

The goal of this study is to understand how moisture availability, collection site of dust, and substrate type impact microbial growth and mVOC production. We want to better predict $\mathrm{mVOC}$ emissions in regard to microbial growth as well as VOC emissions from a variety of substrates under a range of humidity conditions. Samples of dust, carpet, and drywall were subjected to various relative humidity levels, ranging from 50\% - 95\% equilibrium relative humidity (ERH), to evaluate differences in microbial growth and $\mathrm{VOC} / \mathrm{mVOC}$ emissions. The results have implications for understanding and controlling mVOC emissions in damp homes as well as the relationship between health associations and moldy odor.

\section{Methods}

\section{Sample collection}

Nylon cut pile carpet (carpet A) and nylon loop pile carpet (carpet B) were purchased five months prior to sampling incubations. Carpet A contained soil and stain resistant treatments with no antimicrobial treatment while carpet B contained no soil protection but did contain an antimicrobial treatment. The carpets were cut into $5 \mathrm{~cm} \times 5 \mathrm{~cm}$ squares, wrapped in aluminum foil, autoclaved for 60 minutes, and then dried overnight at $30^{\circ} \mathrm{C}$ to sterilize the carpet. Dust was collected from three different parts of the United States: San Francisco Bay Area, CA (three homes), Columbus, OH (three homes) and Gainesville, FL (five homes), from homes without known history of mold and dampness as to not influence the results of our study. Study procedures were reviewed by the University of California IRB, protocol 2018-07-11235. Dust from the same location was mixed together and hand sieved to $250 \mathrm{~nm}$ to remove large particles. The dust was homogenized to minimize impacts to the microbial community due to home differences. A subset of the homogenized dust was sent to Steris Corporation (Petaluma, CA) to be ionized with 10 kGy radiation in attempt to create sterilized dust 
samples. $100 \mathrm{mg}$ of dust was embedded into each preautoclaved carpet square using a modified version of the American Society for Testing and Materials (ASTM) method F608-18, in which a $12 \mathrm{~cm}$ long $1440 \mathrm{~g}$ steel pipe covered in baked aluminum foil was rolled over the carpet squares 30 times.

Gypsum drywall was separated out into two groups (A and $B$ ) based on the paint coating: drywall $A$ was painted with low VOC interior latex flat white paint, while drywall $\mathrm{B}$ was painted with interior acrylic latex flat wall paint. The drywall was cut into $5 \mathrm{~cm} \times 5 \mathrm{~cm}$ squares, wrapped in aluminum foil and autoclaved. The samples were then separated into groups and left to naturally inoculate for four weeks in four separate homes: two in the San Francisco Bay Area, CA (CA 1 and CA 2) and two in Columbus, $\mathrm{OH}(\mathrm{OH} 1$ and $\mathrm{OH} 2)$. A list of all sample types and characteristics as well as samples used in each experiment type can be found in Table 1 and Table 2 respectively. More information about where the carpet and drywall samples were inoculated can be found in the Online Supplementary Information.

\section{Moisture availability incubations}

The first set of experiments was designed to determine the relative humidity inflection point, or the relative humidity level at which microbial growth and microbiallymediated chemical emissions increases in the different materials. We incubated both carpets embedded with dust and drywall at ERH values of $50 \%, 65 \%, 70 \%, 75 \%$, $80 \%, 85 \%$ and $95 \%$ for four weeks. ERH is the relative humidity of the sealed headspace above the material (carpet, dust drywall). At equilibrium conditions the water activity and relative humidity are equal, however the water activity of building materials cannot be measured [45]. Therefore, we measured the equilibrium relative humidity and utilized salt solutions to simulate these ERH conditions [19]. To create water activity levels of $0.50,0.65,0.70,0.75,0.80,0.85$ and 0.95 , salt solutions were made using $\mathrm{NaCl}$ and $\mathrm{MgCl}_{2}$ [18]. The water activity of the salt solutions was tested for accuracy using an AquaLab ${ }^{\text {tw }}$ PawKit Water Activity Meter (Decagon 125 Devices, Pullman, WA, USA). For this sample set, San Francisco Bay Area, CA dust embedded into carpet $\mathrm{A}$ and inoculated drywall $\mathrm{A}$ in $\mathrm{CA}$ home $\mathrm{A}$

Table 1 Descriptions of carpet and drywall types used in sampling

\begin{tabular}{lll}
\hline Sample ID & Material Type & Characteristics \\
\hline Carpet A & Nylon carpet & Cut pile; soil and stain resistant treatment \\
Carpet B & Nylon carpet & Loop pile; antimicrobial treatment \\
Drywall A & Gypsum drywall & Low VOC interior latex flat white paint \\
Drywall B & Gypsum drywall & Interior acrylic latex flat wall paint \\
\hline
\end{tabular}

were utilized and incubated at each of the ERH conditions. Samples of autoclaved "non-microbial" carpet A and drywall A were incubated as controls. The samples were placed into $1 \mathrm{~L}$ incubation jars, with triplicates in each jar and incubated for $\sim 4$ weeks at $25^{\circ} \mathrm{C}$.

When collecting dust from the samples of carpet with dust incubated at 95\% $\mathrm{ERH}$, one challenge was how to prevent excessive moisture accumulation in the carpet. For instance, while incubating samples at 95\% ERH, water had condensed on the sides and bottom of the incubation jar resulting in visibly moist carpet. Therefore, the dust was not able to be efficiently vacuumed due to excessive moisture in the carpet. While growth was visible on the carpet, only a low quantity of dust was collected on the filter and estimates of biomass through qPCR were not possible. We incubated new samples of carpet A embedded with CA dust at 95\% ERH for four weeks in a larger open mouth jar to allow for air to pass efficiently through the parafilm and prevent a visibly moist carpet. This new sample was used for qPCR microbial quantification analysis and the original sample was used for species composition.

\section{Collection location}

Samples from the different building materials (carpet A, carpet $\mathrm{B}$, drywall $\mathrm{A}$, drywall $\mathrm{B}$ ) as well as the homogenized dust samples that were collected in $\mathrm{CA}, \mathrm{OH}$, or $\mathrm{FL}$, were utilized to determine variations in microbial growth, mVOC, and VOC emissions (Table 2). Each sample type was incubated in duplicate in separate glass jars covered with parafilm. Samples were incubated at either $50 \%$ ERH or $85 \%$ ERH for four weeks at room temperature using the same method described previously. Once the incubations were complete, VOC/ mVOC emissions were sampled using a direct sampling approach.

\section{VOC measurement}

VOCs were measured using an Ionicon proton-transferreaction time-of-flight mass spectrometer (PTR-TOF$\mathrm{MS})$, a new system that allows for VOC measurements at high time $(<1 \mathrm{~s})$ and mass $(>5000 \mathrm{~d} / \mathrm{dm})$ resolution, high sensitivity and an ultra-low detection limit [46]. The PTR-TOF-MS (PTR-TOF 8000, IONICON Analytik $\mathrm{GmbH}$ ) detects VOCs in real-time through a proton transfer reaction that takes place between a sample gas and the produced $\mathrm{H}_{3} \mathrm{O}^{+}$ions form the ion source [46]. It records the mass spectrum as a mass to charge ratio $(\mathrm{m} /$ z) of typically 10.000-500.000 at a rate of $0.1-10 \mathrm{~Hz}$, using the primary ion reagent $\mathrm{H}_{3} \mathrm{O}^{+}[27,47]$. In our experiments, the time resolution was set at 5-s consistently. A multi-port flow-through valve system in conjunction with a flow-through multi-chamber approach was used to measure up to eight samples in a 60- 
Table 2 Sample information for the two main experiments: Moisture Availability and Collection Location Samples.

\section{Experiment Name \\ Moisture Availability \\ Samples}

\section{Description}

Samples incubated at 50\%, 65\%, 70\%, 75\%, 80\%, 85\% and 95\% ERH for 4 weeks at $25^{\circ} \mathrm{C}$. Chemical emissions were measured using the flow-through chamber approach in which emissions were measured for a total of 2 hours.

Carpet

Carpet A sterilized (control)

Carpet A with CA dust

Drywall

Painted Drywall A sterilized (control)

Painted Drywall A inoculated in CA home 1

\section{Collection Location}

Samples

Duplicates of each sample type were incubated at 50\% and 85\% ERH for 4 weeks at ambient room temperature. Chemical emissions were measured using a direct sampling approach in which the sampling line for the volatile chemistry instrument was inserted into the parafilm covering the jar of an individual sample.

\section{Carpet}

\author{
Carpet A sterile (control) \\ Carpet B sterile (control) \\ Carpet A with CA dust \\ Carpet A with $\mathrm{OH}$ dust \\ Carpet A with FL dust \\ Carpet A with irradiated CA dust (control) \\ Carpet A with irradiated $\mathrm{OH}$ dust (control) \\ Carpet A with irradiated FL dust (control) \\ Carpet B with CA dust \\ Carpet $\mathrm{B}$ with $\mathrm{OH}$ dust \\ Carpet B with FL dust
}

\section{Dust}

$$
\begin{aligned}
& \text { Irradiated CA dust (control) } \\
& \text { Irradiated } \mathrm{OH} \text { dust (control) } \\
& \text { Irradiated } \mathrm{FL} \text { dust (control) } \\
& \text { Original collected non-incubated dust from } \mathrm{CA} \\
& \text { Original collected non-incubated dust from } \mathrm{OH} \\
& \text { Original collected non-incubated dust from } \mathrm{CA}
\end{aligned}
$$

\section{Drywall}


minute cycle, with each sample chamber being individually measured for 7.5 minutes. The chambers made of glass and VOC-compatible materials (Teflon ${ }^{\circ}$ lid) were continually flushed throughout the experiments at $0.2 \mathrm{~L} / \mathrm{min}$ of zero-air generated by the Ultra High Purity Zero Air Generator (ZAG) (Aadco, Cleves, OH, USA), which was connected to a glass bubbler to produce the desired ERH condition throughout the chambers. The ZAG produces VOC free air that contains ultra-low concentration of impurities and $\mathrm{CO}_{2}$ ensuring that the background concentration in the air is zero. The sample chambers were connected to both the humidity controlled zero air supply and the PTR-TOF-MS by $1.6 \mathrm{~mm}(1 / 16$ ") polyether ether ketone (PEEK) tubing. A negative control chamber was included in each set of samples to measure the baseline emission levels from the instrument setup to account for the concentration and emission rates calculations. A similar setup was used in Misztal (2018) and a diagram of the experimental setup can be found in the Supporting Information in the referenced manuscript [27].

The moisture availability samples were sampled using the flow-through chamber approach, in which a sample was placed in one of seven chambers. An eighth jar was used as a negative control. Each chamber was individually sampled twice for 7.5 minutes each time, leading to an overall sampling time of two hours. For the collection location samples, a direct approach to sampling was applied, as the sampling line for the PTR-TOF-MS was inserted into the parafilm covering the chamber of an individual sample. The sampling time was also significantly shorter than the moisture availability samples, as each collection location sample was only sampled for two to three minutes total.

Calibrations were performed using a gas mixture that contained compounds representative for both microbial and non-microbial sources. The gas mixture was prepared by Apel-Reimer (Miami, FL, USA) and has a guaranteed $+/-5 \%$ accuracy [48]. The gas standard was composed of compounds detectable at the following $\mathrm{m} / \mathrm{z}$ ratios, representative of the protonated parent compounds: 33.034, $47.05,69.034,59.05,63.027,85.029,93.071,97.029$, $118.066,145.159,153.128,155.09,205.196,234.876$, 371.102. Some semi volatile compounds (e.g. nonanal, indole, citral) with very low vapor pressures were not included in sensitivity and transmission calculations due to potential losses. $\mathrm{CO}_{2}$ and $\mathrm{H}_{2} \mathrm{O}$ concentrations within each chamber were measured for each experiment using a Licor LI-840. The measurements for CO2 (ppm) and $\mathrm{H}_{2} \mathrm{O}$ $(\% \circ)$ were taken at a 1-s time resolution.

\section{Microbial analysis.}

\section{DNA extraction and sequencing}

Each carpet square was vacuumed, and dust was collected using a sterile $37 \mathrm{~mm}$ Air/Liquid Sampling
Cassette 3-Piece w/0.45um Gridded MCE Filter (Zeflon International, FL USA) connected to the laboratory vacuum system at a flow rate of $47 \mathrm{~L} / \mathrm{min}$. To prepare for DNA extractions, the collected dust was weighed into 50 $\mathrm{mg}$ aliquots and placed in $2.0 \mathrm{~mL}$ screw top vials. To collect microbes from the drywall samples, the top of the painted drywall was swabbed with a Puritan ${ }^{\circ}$ Sterile Cotton Tipped Applicator that had been dipped in TrisEDTA. The swab tip was then cut and placed in a 2.0 $\mathrm{mL}$ screw top vial.

DNA was extracted and processed for $\mathrm{qPCR}$ and amplicon sequencing following the protocols described in Haines (2020)[19]. Sequence data was submitted to the European Nucleotide Archive under accession number PRJEB41403. Detailed methods regarding qPCR and DNA sequencing analysis can be found in the Supplementary Information.

\section{Chemical analysis}

The raw data from the PTR-TOF-MS was pre-processed using PTRwid [49] and MATLAB ${ }^{\circ}$ [50]. General process routines included trimming and removal of poor-quality data, subtraction of Zero Air, processing calibrations and applying sensitivities.

The emission rates $\left(\mu \mathrm{g} \mathrm{hr}^{-1}\right)$ were calculated from the corresponding concentration data (ppb) for the moisture availability samples. The emissions factor $\left(\mu \mathrm{g} \mathrm{hr} \mathrm{g}^{-1}\right)$ was calculated by dividing the emissions rate by the weight of the carpet sample. Pre-experimental runs on clean empty chambers showed consistent and small trace backgrounds of VOCs which were typically zero or close to zero (typically several orders of magnitude lower than those measured from the samples). In addition, the negative control that was included in each group of samples was used to subtract potential trace emissions from the non-sample sources (chambers, petri dishes, or any other chemical background traces of emissions in the system set-up). Emissions were calculated using the formula that is outlined in the Supplementary Information. The collection location samples were measured using a direct headspace sampling approach instead of the flowthrough chamber approach. This allows for a large volume of samples to be processed in a short duration; however, it limits the interpretation of the data to a semiquantitative approach. Therefore, no emission rates were calculated for the collection location samples, and instead the concentration fingerprints were examined for a variety of samples and translated into a categorical representation of either "present" or "not present."

There is high confidence in the assigned chemical formulas and in the formulas determined using the protonated mass. However, the exact compound structure the formula represents in multi-isomer cases cannot be structurally speciated. A "compound consistent with 
chemical formula" was appointed to most chemical formulas based on both the properties of the specific compound (e.g. vapor pressure, boiling point, known sources) and on the properties of the sample itself. Expert opinion was utilized when selecting these consistent compounds to ensure that the most accurate conclusion was drawn. All chemical formulas are represented with the chemical ionization method of that ion, which in the majority of cases is a proton transfer reaction resulting in $\mathrm{H}^{+}$addition to the formula. A more detailed description of both the process of formula identification and compound identification are contained in the Supplementary Information.

\section{Statistical analysis}

Statistical Analysis System (SAS), version 9.4 (SAS Institute, Inc) was utilized to determine comparisons within the taxonomy and chemical emissions for the moisture availability samples. The average emissions were found across the entire mass range for each individual sample replicate, and three replicates were used for each sample group. A table with all of the statistical tests performed can be found in Supplemental Information Table S1. Comparisons were made between emission rates from different samples type (carpet, dust, drywall) and humidity levels. The MULTTEST Procedure with the false discovery rate (FDR) adjustment [51], was utilized to determine the statistical significance $(p<0.05)$ of different variables impacting the taxonomy of samples as well as the significance of chemical emissions at different humidity levels. The FDR adjustment uses the linear stepup method that is described in Benjamini and Hochberg (1995), in which the p-value may control the false discovery rate. Each data set was normalized using the inverse hyperbolic sine (IHS) transformation, which, unlike a logarithmic transformation, allows for values $<1$ and $0[18,19,52,53]$.

For fungi and bacteria, only species that were detected in $\geq 20 \%$ of samples in each sample set were included in the statistical analysis. For the "moisture availability samples" sample sets were separated by carpet and drywall in which species found in $\geq 20 \%$ of carpet A with CA home 1 dust (328 fungal species and 156 bacterial species) were utilized for the carpet analysis and species found in $\geq 20 \%$ of painted drywall A inoculated in CA home 1 (235 fungal species and 53 bacterial species) were utilized for the drywall analysis. For the "collection location samples", as comparisons were made between collection locations, sample type and relative humidity, only species found in $\geq 20 \%$ of all collection location samples (582 fungal species and 157 bacterial species) were utilized in the statistical analysis. In QIIME, the adonis method was used to determine the statistical significance of taxonomic sample groupings from the beta diversity distance matrices, Bray-Curtis for fungi and Unifrac for bacteria. Relative humidity groupings based on species composition in carpet with dust samples and inoculated drywall samples were first observed by creating large heat maps using the quantity of each species and sorting by abundance. Using these visual cues from the heat maps, we tested the significance of the groupings of species based on relative humidity level through adonis in QIIME. Adonis was also used on the chemical emissions data in RStudio using Euclidean distances [54]. The statistical tests explored the role of relative humidity, sample type, and collection site on microbial and chemical emissions.

\section{Results}

\section{Determination of relative humidity level required to} support growth

Fungal growth was measured in carpet samples with CA dust and painted drywall inoculated in CA home 1 at different RH levels. Growth in CA carpet A with dust was determined to occur somewhere between $75 \% \mathrm{ERH}$ and $80 \% \mathrm{ERH}$, while growth in drywall was observed to occur between 85\% ERH and 95\% ERH (Fig. 1A and B). Penicillium was abundant in both the carpet and drywall samples at 95\% ERH, while Wallemia and Aspergillus were abundant in carpet and Cladosporium on drywall. No clear growth patterns were observed for bacteria in these samples (Figure S1).

Fungal communities statistically significantly varied by ERH condition in both carpet and drywall (Fig. 2A, adonis $\mathrm{R}^{2}=0.17, p=0.003$, Fig. $2 \mathrm{~B}$, adonis $R^{2}=0.16, p=0.002$ respectively). The fungal species composition of carpet with CA dust were statistically associated with three distinct groups based on relative humidity condition: Low $\mathrm{ERH}=50 \%, 65 \%$ and $70 \%$, Medium ERH $=75 \%, 80 \%$ and $85 \%$ and High ERH $=95 \%\left(R^{2}=0.18, p=0.001\right)$ (Fig. 3, Figure S2 \& S3). Species within the genera Penicillium, Aspergillus, Alternaria, and Cladosporium were associated with the High ERH condition when compared to the Medium and Low ERH condition (Table S2), while Wallemia species were more associated with the Medium ERH condition than Low ERH (Table S3). Many species were more statistically significantly associated with the Low ERH condition than the High and Medium conditions (Table S4).

The adonis statistical analysis revealed that the fungal communities on the painted drywall samples also grouped into three categories based on relative humidity, although the cutoff values for the groups differed from carpet: 50\%-80\% ERH (Low), 85\% ERH (Medium) and 95\% ERH (High) $\left(R^{2}=0.25, p=0.001\right)$ (Fig. 4 \& S4). Cladosporium, Penicillium and Alternaria species were more associated with 95\% ERH when compared to samples incubated at 50\%-80\% ERH or 85\% ERH (Table S5). 


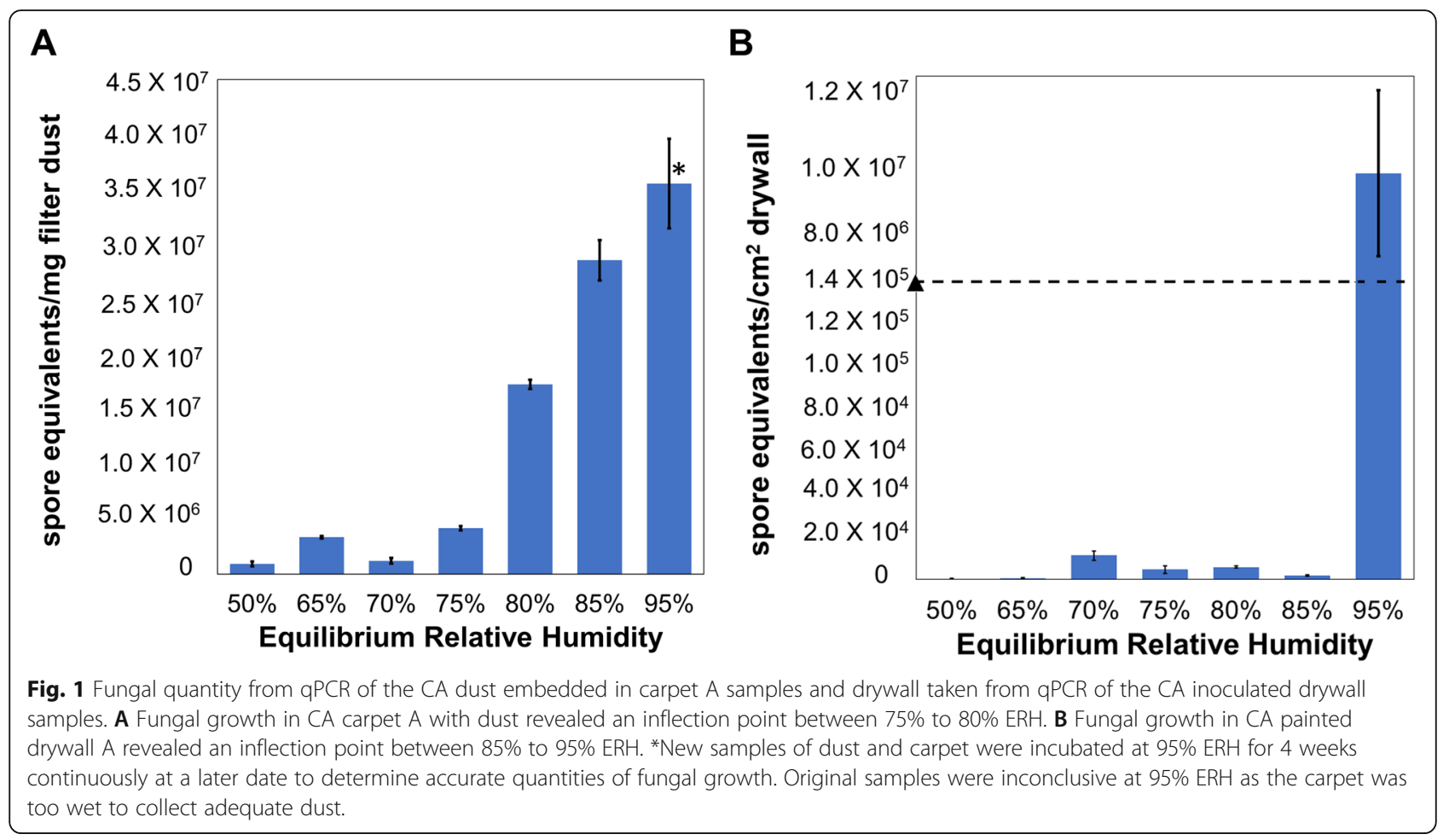

Penicillium kongii, Penicillium citrinum, Penicillium phoeniceum, Aspergillus clavatus, and Aspergillus carbonarius were all associated with the $85 \%$ ERH condition compared to the 50\%-80\% ERH condition (Table S6).

For the carpet and dust samples, the bacterial communities statistically significantly separated by relative humidity condition (Unweighted Unifrac $\mathrm{R}^{2}=0.13, p=$ 0.001 \& Weighted Unifrac $\mathrm{R}^{2}=0.31, p=0.002$ )(Fig. 5A and B). Bacterial communities in carpet samples with CA dust statistically separated into four groups based on relative humidity: $50 \%-65 \%, 70 \%-75 \%, 80 \%-85 \%$, and 95\% (Unweighted Unifrac $\mathrm{R}^{2}=0.15, \quad p=0.001 \&$
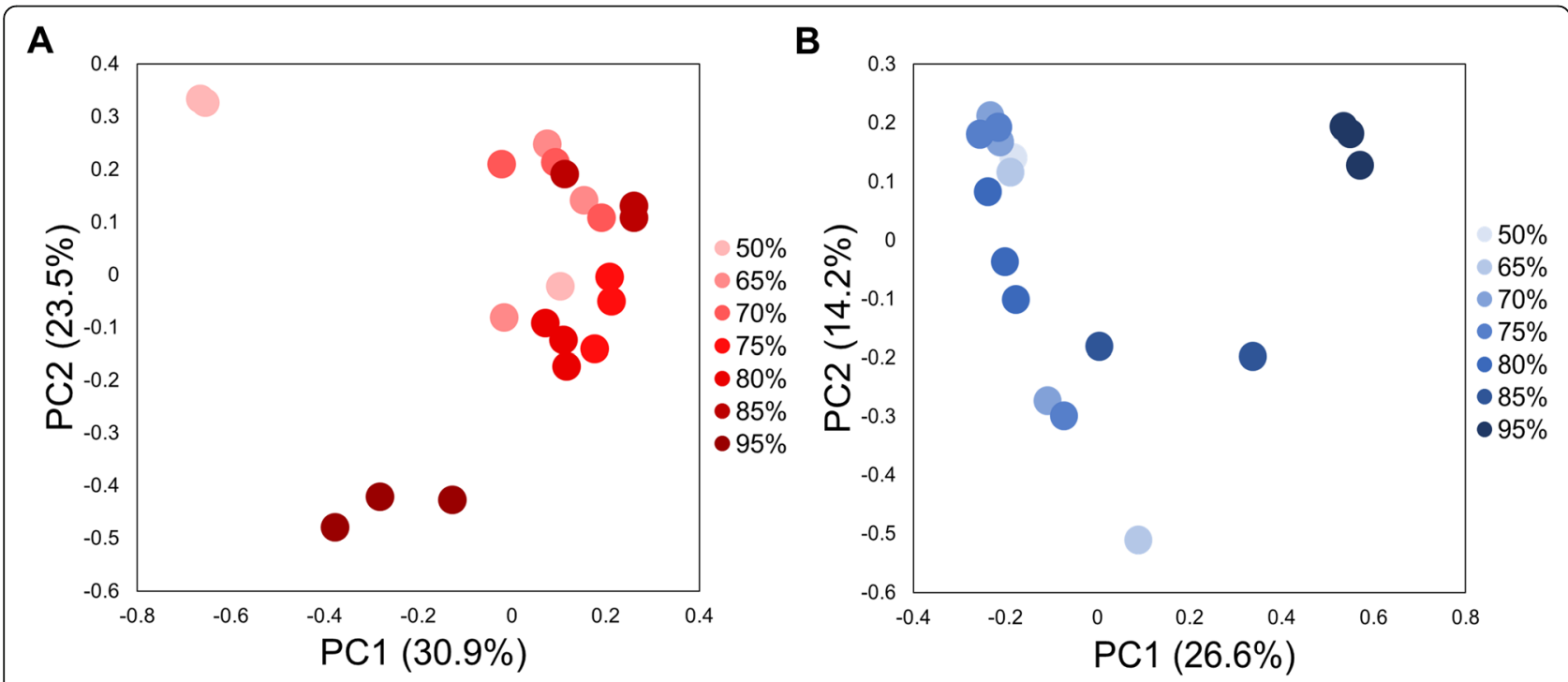

Fig. 2 Fungal PCoA plot of the CA dust embedded in carpet A (A) and samples of inoculated CA painted drywall A (B) incubated at different relative humidity conditions $(50 \%, 65 \%, 70 \%, 75 \%, 80 \%, 85 \%, 95 \%)$ for 4 weeks. 


\begin{tabular}{|c|c|c|c|c|c|c|c|c|}
\hline \multirow[b]{2}{*}{ Fungal Species } & \multicolumn{3}{|c|}{ Low } & \multicolumn{3}{|c|}{ Medium } & \multirow{2}{*}{\begin{tabular}{|l} 
High \\
$\mathbf{9 5 \%}$
\end{tabular}} & \multirow[b]{2}{*}{ spore $\mathrm{eq} / \mathrm{mg}$ filter dus } \\
\hline & $50 \%$ & $65 \%$ & $70 \%$ & $75 \%$ & $80 \%$ & $85 \%$ & & \\
\hline \multicolumn{8}{|l|}{ Penicillium chrysogenum } & $>1,000,000$ \\
\hline \multicolumn{9}{|l|}{ Aspergillus hongkongensis } \\
\hline \multicolumn{9}{|l|}{ Penicillium gladioli } \\
\hline \multicolumn{9}{|l|}{ Wallemia tropicalis } \\
\hline \multicolumn{9}{|l|}{ Penicillium kongii } \\
\hline \multicolumn{9}{|l|}{ Wallemia muriae } \\
\hline \multicolumn{9}{|l|}{ Wallemia canadensis } \\
\hline \multicolumn{9}{|l|}{ Aspergillus ruber } \\
\hline \multicolumn{9}{|l|}{ Wallemia sebi } \\
\hline \multicolumn{9}{|l|}{ Cladosporium halotolerans } \\
\hline \multicolumn{9}{|l|}{ Penicillium decumbens } \\
\hline \multicolumn{9}{|l|}{ Candida parapsilosis } \\
\hline \multicolumn{9}{|l|}{ Cladosporium sphaerospermum } \\
\hline \multicolumn{9}{|l|}{ Cladosporium dominicanum } \\
\hline \multicolumn{9}{|l|}{ Aspergillus conicus } \\
\hline \multicolumn{9}{|l|}{ Epicoccum nigrum } \\
\hline \multicolumn{9}{|l|}{ Talaromyces minioluteus } \\
\hline \multicolumn{9}{|l|}{ Aspergillus restrictus } \\
\hline \multicolumn{9}{|l|}{ Cladosporium delicatulum } \\
\hline \multicolumn{9}{|l|}{ Nigrospora oryzae } \\
\hline \multicolumn{9}{|l|}{ Mycosphaerella tassiana } \\
\hline \multicolumn{9}{|l|}{ Hamigera insecticola } \\
\hline \multicolumn{9}{|l|}{ Pseudopithomyces chartarum } \\
\hline \multicolumn{9}{|l|}{ Coniosporium apollinis } \\
\hline Vishniacozyma victoriae & & & & & & & & \\
\hline Xenodidymella humicola & & & & & & & & \\
\hline Aspergillus penicillioides & & & & & & & & \\
\hline Didymella gardeniae & & & & & & & & \\
\hline Vishniacozyma carnescens & & & & & & & & \\
\hline
\end{tabular}

Fig. 3 Heatmap of the 29 most abundant species found in at least 70\% of the CA carpet with dust samples for the moisture availability tests. An additional heatmap showing fungal species found in at least 20\% of all samples can be found in Supplementary Information Figure S2. Species statistically separated into three categories, Low (50\%-70\%), Medium (75\%-85\%) and High (95\%) $\left(R^{2}=0.18, p=0.001\right)$.

Weighted Unifrac $\mathrm{R}^{2}=0.36, p=0.001$ ) (Figure S6). Certain bacterial species, such as Staphylococcus aureus, Serratia marcescens, Pseudomonas viridiflava, Acinetobacter johnsonii, and Janthinobacterium lividum, among others, were more associated with $50 \%-85 \%$ when compared to 95\% ERH (Table S7). Streptococcus, Staphylococcus, Sphingomonas, Corynebacterium and Pseudomonas were the most abundant bacterial genera found in carpet with CA dust (Figure S6).

Similar to the dust embedded in carpet samples, the abundant genera in the painted inoculated drywall consisted of Corynebacterium, Sphingomonas, Staphylococcus and Streptococcus (Figure S7). In painted drywall A, Rothia mucilaginosa and Methylobacterium adhaesivum were found in abundance in the 95\% ERH samples
(Figure S7). In fact, each ERH condition contained different abundant bacterial species in the drywall samples when compared across ERH incubation (Table S8).

Microbial diversity associated with material type and collection location

Composition of fungal and bacterial communities statistically differed based on the material type and collection site (Table S9). Fungal and bacterial communities were different in carpet compared to drywall samples (BrayCurtis, adonis $R^{2}=0.26, p=0.001$ )(Figure S8), Unweighted Unifrac $\mathrm{R}^{2}=0.23, p=0.001$ \& Weighted Unifrac, adonis $R^{2}=0.48, p=0.001$ )(Figure S9). When comparing material type, carpet was associated with higher concentrations of 411 fungal species, while 


\begin{tabular}{|c|c|c|c|c|c|c|c|c|}
\hline \multirow[b]{2}{*}{ Fungal Species } & \multicolumn{5}{|c|}{ Low } & \multirow{2}{*}{\begin{tabular}{|c|}
$\mid$ Medium \\
$85 \%$
\end{tabular}} & \multirow{2}{*}{$\begin{array}{l}\text { High } \\
95 \%\end{array}$} & \multirow[b]{2}{*}{ spore eq $/ \mathrm{cm}^{2}$ drywall } \\
\hline & $50 \%$ & $65 \%$ & $70 \%$ & $75 \%$ & $80 \%$ & & & \\
\hline \multirow{2}{*}{\multicolumn{8}{|c|}{$\begin{array}{l}\text { Penicillium citrinum } \\
\text { Cladosporium sphaerospermum }\end{array}$}} & $>1,000,000$ \\
\hline & & & & & & & & $>100,000$ \\
\hline \multicolumn{9}{|c|}{$\begin{array}{l}\text { Cladosporium sphaerospermum } \\
\text { Cladosporium dominicanum }\end{array}$} \\
\hline \multicolumn{9}{|l|}{ Cladosporium ramotenellum } \\
\hline \multicolumn{9}{|l|}{ Penicillium chrysogenum } \\
\hline \multicolumn{9}{|l|}{ Mycosphaerella tassiana } \\
\hline \multirow{2}{*}{\multicolumn{9}{|c|}{$\begin{array}{l}\text { Cladosporium halotolerans } \\
\text { Alternaria alternata }\end{array}$}} \\
\hline & & & & & & & & \\
\hline \multirow{2}{*}{\multicolumn{9}{|c|}{$\begin{array}{l}\text { Cladosporium delicatulum } \\
\text { Penicillium kongii }\end{array}$}} \\
\hline & & & & & & & & \\
\hline \multicolumn{9}{|l|}{ Penicillium brevicompactum } \\
\hline \multicolumn{9}{|l|}{ Penicillium gladioli } \\
\hline \multicolumn{9}{|l|}{ Alternaria brassicae } \\
\hline \multicolumn{9}{|l|}{ Alternaria metachromatica } \\
\hline \multicolumn{9}{|l|}{ Wallemia tropicalis } \\
\hline \multirow{2}{*}{\multicolumn{9}{|c|}{$\begin{array}{l}\text { Wallemia canadensis } \\
\text { Cladosporium fusiforme }\end{array}$}} \\
\hline & & & & & & & & \\
\hline \multicolumn{9}{|l|}{ Wallemia muriae } \\
\hline \multicolumn{9}{|l|}{ Candida parapsilosis } \\
\hline \multicolumn{9}{|l|}{ Epicoccum nigrum } \\
\hline \multirow{2}{*}{\multicolumn{9}{|c|}{$\begin{array}{l}\text { Aureobasidium namibiae } \\
\text { Curvularia neergaardii }\end{array}$}} \\
\hline & & & & & & & & \\
\hline \multicolumn{9}{|l|}{ Aspergillus ruber } \\
\hline \multicolumn{9}{|l|}{ Vishniacozyma victoriae } \\
\hline \multicolumn{9}{|l|}{ Claviceps grohii } \\
\hline Cladosporium aphidis & & & & & & & & \\
\hline Cystofilobasidium macerans & & & & & & & & \\
\hline Torula herbarum & & & & & & & & \\
\hline Botrytis caroliniana & & & & & & & & \\
\hline Podosphaera leucotricha & & & & & & & & \\
\hline Botrytis cinerea & & & & & & & & \\
\hline Coniosporium apollinis & & & & & & & & \\
\hline Aureobasidium pullulans & & & & & & & & \\
\hline Rhodotorula mucilaginosa & & & & & & & & \\
\hline Rhodotorula dairenensis & & & & & & & & \\
\hline
\end{tabular}

drywall was only associated with higher concentrations of nine fungal species (Table S10). Within a material sample type, the location of the collection influenced the composition of both fungal and bacterial communities (Fig. 6 \& Table S9). Different fungal species were determined to be abundant at $85 \%$ ERH for each location, FL, CA and $\mathrm{OH}$ (Figure S10, Figure S11 \& Figure S12). Fungal species associated with a specific location of collection site when compared to the other locations can be found in the Supporting Information (Table S11, S12 \& S13).

When comparing relative humidity among all sample types in the moisture availability samples, ERH level was statistically significant for fungal and bacterial growth (Bray-Curtis $\mathrm{R}^{2}=0.04, p=0.04$; Weighted Unifrac $\mathrm{R}^{2}=$
0.05, $p=0.04$; Unweighted Unifrac $\mathrm{R}^{2}=0.04, p=0.01$ ). However, no statistical taxonomic differences were found when comparing the ERH level (50\% or 85\%) across all sample types from the collection site samples (Bray-Curtis $\mathrm{R}^{2}=0.02, p=0.08$; Weighted Unifrac $\mathrm{R}^{2}=$ 0.005, $p=0.9$; Unweighted Unifrac $\mathrm{R}^{2}=0.01, p=0.8$ ). Within samples from only $\mathrm{CA}$ or only $\mathrm{OH}$, no distinct difference in fungal communities were observed between carpet type or relative humidity condition (50\% vs $85 \%)$ (Figure S13A \& S13B) $\left(R^{2}=0.05, p=0.86\right.$ and $\mathrm{R}^{2}=0.08$, $p=0.25$ respectively). However, there was a significant difference in fungal communities in carpet with dust samples from FL that were incubated at 50\% ERH compared to $85 \%$ ERH (Figure S13C) $\left(R^{2}=0.22, p=0.021\right.$ ), with more species associated with 50\% ERH than $85 \%$ 

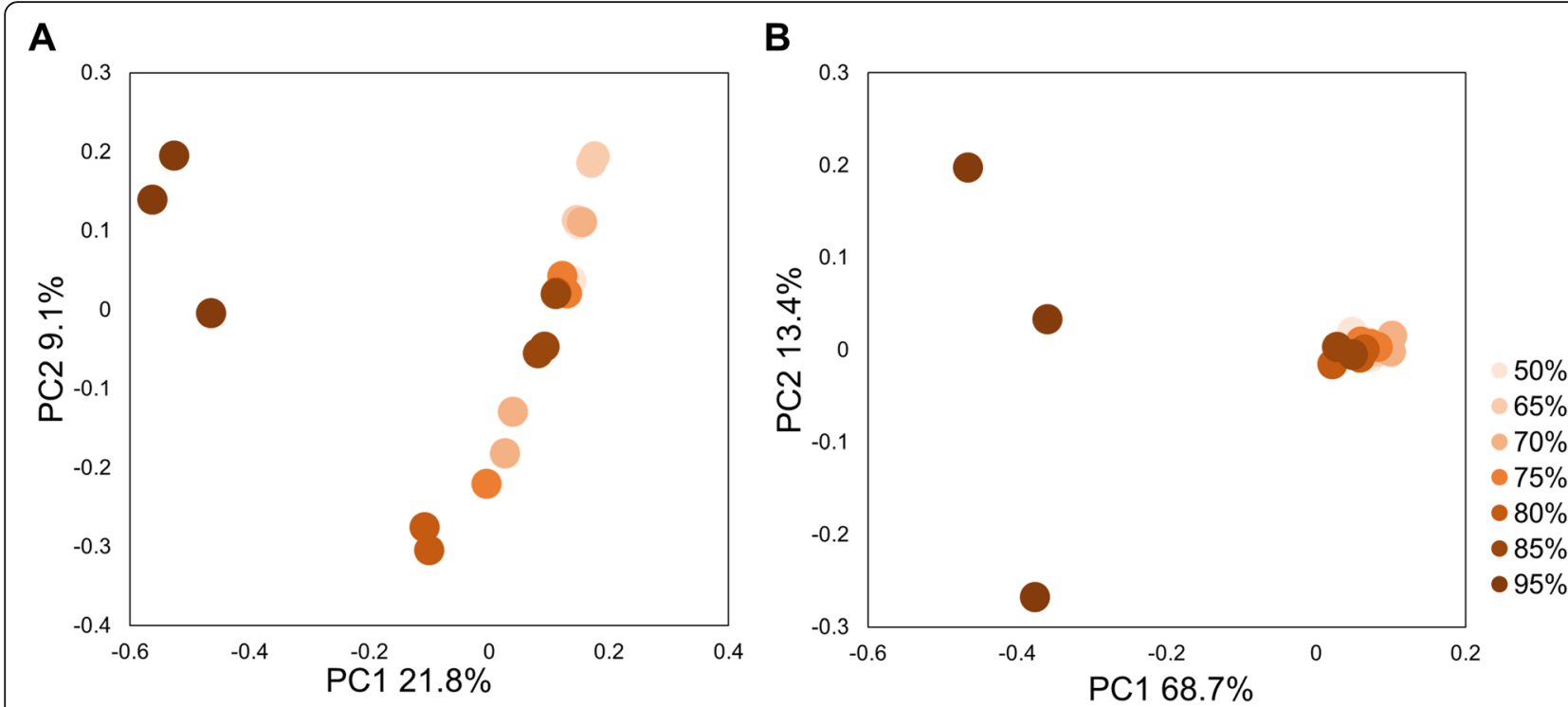

Fig. 5 Bacterial PCoA, using the unweighted unifrac $(\mathbf{A})$ and weighted unifrac $(\mathbf{B})$ distance indices, of the carpet with CA dust from the moisture availability experiments incubated at 50\%,65\%,70\%,75\%,80\%,85\% and 95\% ERH.

ERH (Table S14). There was no significant difference in fungal species comparing carpet A to carpet B when grouping all samples from the collection site locations.

\section{Chemical emissions were dominated by building materials}

The most abundant VOC emissions (in terms of emissions factor) released from carpet and drywall samples were related to the materials themselves, not microbial compounds. The most abundant ( $>1 \%$ concentration) chemical compounds determined in both carpet without dust samples and dust embedded in carpet samples incubated at $95 \%$ ERH were $\mathrm{C}_{5} \mathrm{H}_{10} \mathrm{H}^{+}$, (cyclopentane/pentene), followed by $\mathrm{C}_{4} \mathrm{H}_{8} \mathrm{H}^{+}$, (butanol/butene). However, the majority of compounds emitted from the carpet with dust samples contributed to $<1 \%$ of the total emissions each and were grouped together and classified as "Other" (Fig. 7). Total emissions from carpet with dust samples at $65-80 \%$ ERH ranged from $\sim 1750-2000 \mu \mathrm{g}$ $\mathrm{hr}^{-1} \mathrm{~g}^{-1}$ carpet, while carpet without dust alone samples at $65-80 \%$ ERH ranged from $\sim 750-1500 \mu \mathrm{g} \mathrm{hr}^{-1} \mathrm{~g}^{-1}$ carpet (Fig. 7). Emissions from carpet without dust samples at $95 \%$ ERH emitted more $\mathrm{C}_{5} \mathrm{H}_{10} \mathrm{H}^{+}$than the carpet with dust samples at $95 \%$ ERH. Chemical compounds $\mathrm{C}_{2} \mathrm{H}_{4} \mathrm{O}_{2} \mathrm{H}^{+}$(acetic acid), $\mathrm{CH}_{2} \mathrm{O}_{2} \mathrm{H}^{+}$(formic acid), $\mathrm{C}_{2} \mathrm{H}_{6} \mathrm{OH}^{+}$(ethanol), and $\mathrm{C}_{2} \mathrm{H}_{2} \mathrm{OH}^{+}$(ketene) were more abundantly emitted from samples incubated at 50\% ERH and $65 \%$ ERH while $\mathrm{C}_{3} \mathrm{H}_{4} \mathrm{H}^{+}$(propyne) appeared in abundance in both the carpet without dust and carpet with dust samples at 70\% ERH. $\mathrm{C}_{3} \mathrm{H}_{6} \mathrm{H}^{+}$(propene), $\mathrm{C}_{6} \mathrm{H}_{6} \mathrm{H}^{+}$(benzene), $\mathrm{C}_{5} \mathrm{H}_{10} \mathrm{H}^{+}$(pentene and cyclopentane) and $\mathrm{C}_{3} \mathrm{H}_{5} \mathrm{NO}_{2} \mathrm{H}^{+}$(vinyl carbamate + dehydroalanine), among others were more associated with carpet without dust at 95\% ERH than carpet with dust at 95\% ERH (Table S15).

The abundant $(>1 \%)$ chemical families found in carpet without dust incubated at 75-80\% ERH consisted of $\mathrm{C}_{\mathrm{x}} \mathrm{H}_{\mathrm{y}} \mathrm{O}_{1} \mathrm{H}^{+}, \quad \mathrm{C}_{\mathrm{x}} \mathrm{H}_{\mathrm{y}} \mathrm{N}_{\mathrm{z}} \mathrm{O}_{\mathrm{n}} \mathrm{H}^{+}, \quad \mathrm{C}_{\mathrm{x}} \mathrm{H}_{\mathrm{y}} \mathrm{O}_{2} \mathrm{H}^{+}, \quad \mathrm{C}_{\mathrm{x}} \mathrm{H}_{\mathrm{y}} \mathrm{O}_{3} \mathrm{H}^{+}$, $\mathrm{C}_{\mathrm{x}} \mathrm{H}_{\mathrm{y}} \mathrm{H}^{+}$and $\mathrm{S}$-Containing (sulfur containing) compounds families (Figure S14A). The majority of compounds (92.2\%) associated with the carpet without dust incubated at 95\% ERH were classified as from the family $\mathrm{CxHyH}^{+}$(Figure S14B). Samples of carpet with dust at 75\%-80\% ERH and 95\% ERH emitted similar chemical families (Figure S15A \& S15B). 45.3\% of compounds associated with carpet with dust samples incubated at $95 \%$ ERH were unidentified while around $12.5 \%$ of compounds were classified as S-containing (Figure S15B).

The most abundant compound emitted from the inoculated drywall samples was $\mathrm{C}_{5} \mathrm{H}_{10} \mathrm{H}^{+}$(cyclopentane + pentene), which consistently accounts for $>10 \%$ of the emissions at each ERH level with the exception of the $80 \%$ ERH sample. $\mathrm{C}_{4} \mathrm{H}_{6} \mathrm{O}_{2} \mathrm{H}^{+}$(butyrolactone + butenic acid) made up $42.5 \%$ of the emissions in the $80 \% \mathrm{ERH}$ drywall samples. Autoclaved drywall incubated at High 95\% ERH was associated with compounds such as $\mathrm{CH}_{2} \mathrm{O}_{3} \mathrm{H}^{+}$(performic acid, FDR $p=0.02$ ), $\mathrm{C}_{2} \mathrm{H}_{5} \mathrm{NO}_{2} \mathrm{H}^{+}$ (methyl carbamate, FDR $p=0.02$ ), $\mathrm{C}_{6} \mathrm{H}_{6} \mathrm{O}_{2} \mathrm{H}^{+}$(2-acetylfuran, FDR $p=0.02$ ), $\mathrm{C}_{6} \mathrm{H}_{6} \mathrm{H}^{+}$(benzene, FDR $p=0.04$ ), and $\mathrm{C}_{3} \mathrm{H}_{6} \mathrm{H}^{+}$(propene, FDR $p=0.04$ ) among others when compared to inoculated drywall at High 95\% ERH (Table S16). Only three mass ratios were associated with the inoculated drywall at High 95\% ERH: 77.94 (FDR $p=0.04$ ), 97.95 (FDR $p=0.04$ ) and 314.11 (FDR $p=0.04$ ), though 


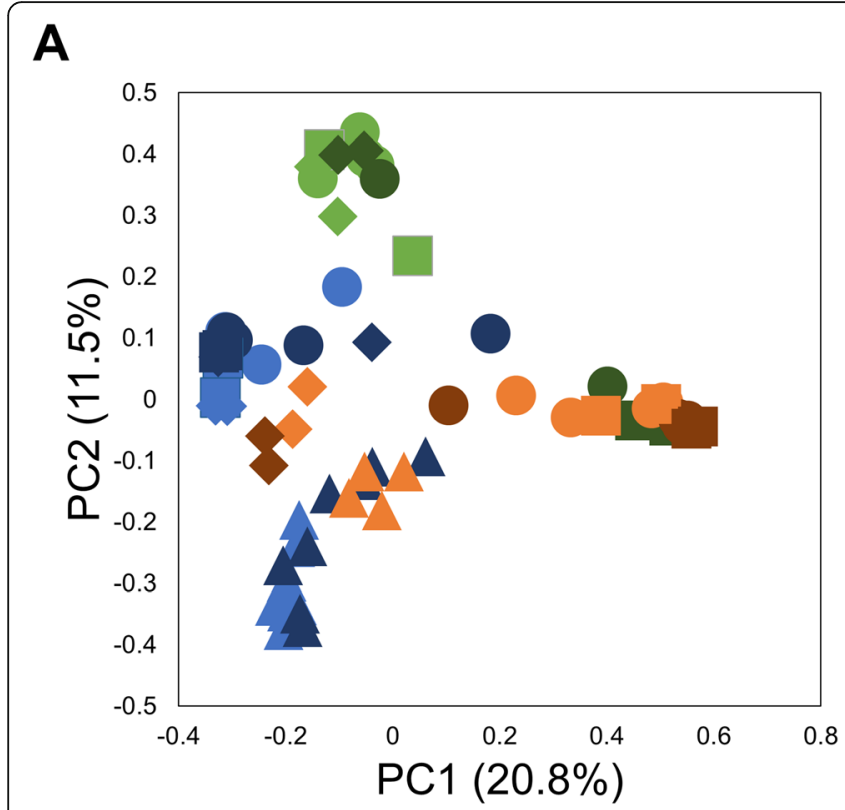

B

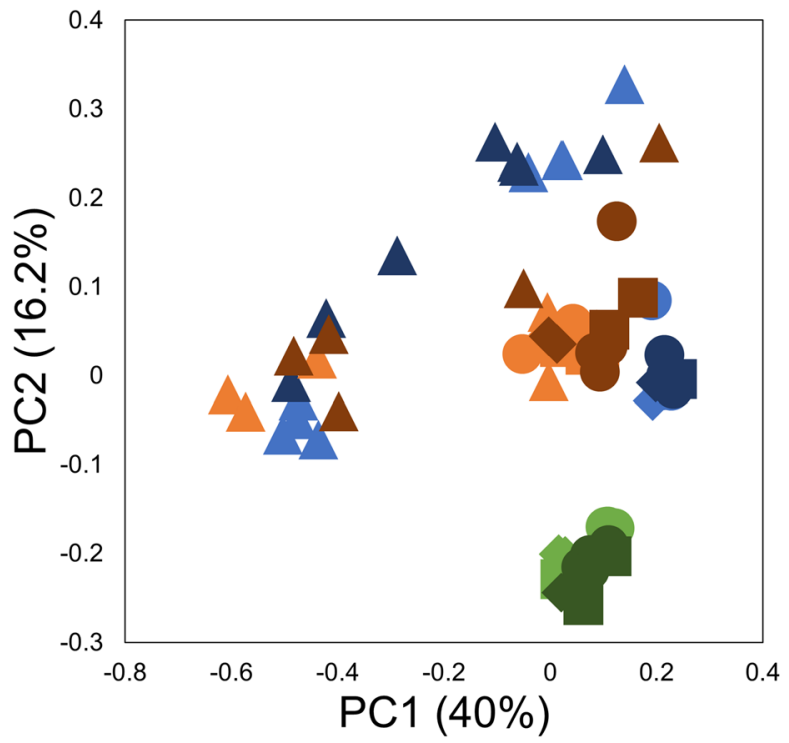

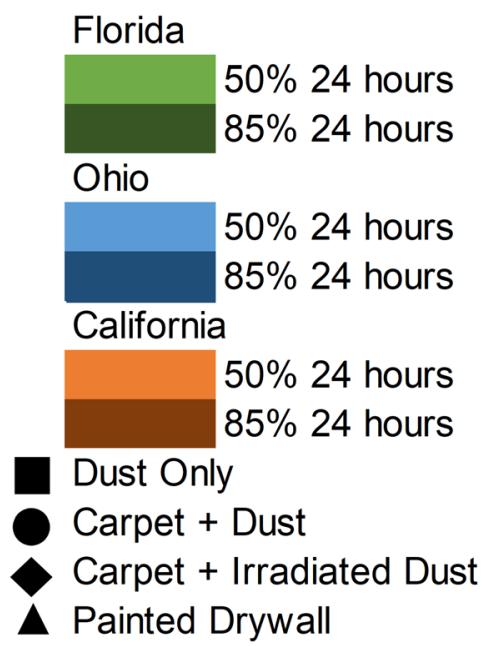

C

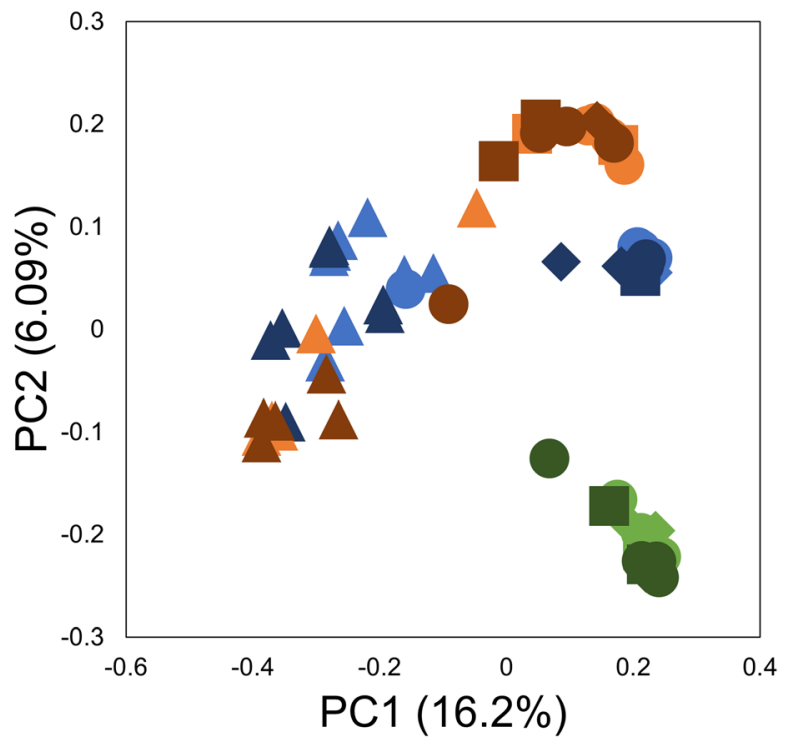

Fig. 6 Principle coordinate analysis (PCOA) of all collection location samples that were incubated at either 50\% ERH or 85\% ERH. A Fungal BrayCurtis analysis, B Bacterial Weighted Unifrac and C Bacterial Unweighted Unifrac where sample separated due to collection site (Florida, Ohio or California) as well as material type.

the chemical formula and compound for these masses are undetermined. However, certain compounds that are likely mVOCs such as $\mathrm{C}_{2} \mathrm{H}_{6} \mathrm{~S}_{2} \mathrm{H}^{+}$and $\mathrm{C}_{2} \mathrm{H}_{6} \mathrm{SO}_{2} \mathrm{H}^{+}$(dimethyl disulfide and dimethyl sulfone, FDR $p=0.03$ ), $\mathrm{C}_{9} \mathrm{H}_{16} \mathrm{H}^{+}$(nonadiene, FDR $p=0.04$ ), $\mathrm{C}_{6} \mathrm{H}_{12} \mathrm{H}^{+}$(1-hexene, $p=0.01$ ) and $\mathrm{C}_{4} \mathrm{H}_{6} \mathrm{O}_{4} \mathrm{H}^{+}$(succinic acid, FDR $p=0.02$ ) were associated with the inoculated drywall at the High ERH condition when compared to the emissions from the inoculated drywall at Low or Medium conditions (Table S17 \& Table S18). The emissions rates over the duration of the sampling time were highest during the first 50 hours of sampling and then decreased. An example of the emissions rate for samples of carpet without dust and carpet with dust incubatde at 50\% ERH can be found in the Supplementary Information Figure S16. (Compounds listed in parentheses are isomers consistent with the chemical formulas, but other isomers are possible.)

\section{mVOCs associated with carpet samples}

Carpet with dust samples incubated at the High (95\% ERH) condition compared to carpet without dust 


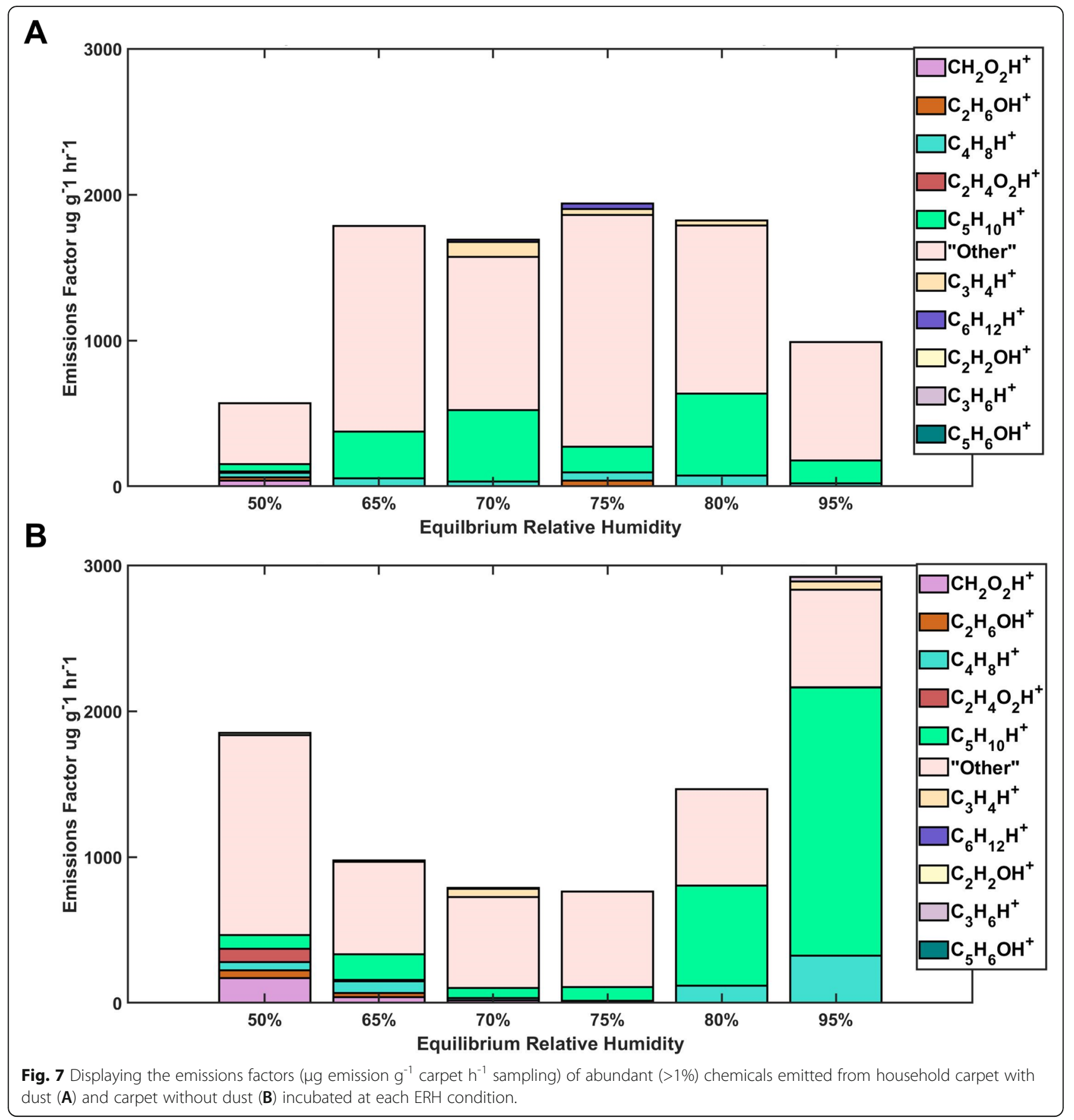

samples incubated at the High (95\% ERH) condition were associated with common indoor mVOCs $\mathrm{C}_{10} \mathrm{H}_{16} \mathrm{H}^{+}$ (monoterpenes, FDR $p=0.004$ ), $\mathrm{C}_{2} \mathrm{H}_{6} \mathrm{SH}^{+}$(dimethyl sulfide + ethanethiol, FDR $p=0.03$ ) and $\mathrm{C}_{10} \mathrm{H}_{12} \mathrm{O}_{2} \mathrm{H}^{+}$(phenethyl acetate, FDR $p=0.01$ ) along with other potential mVOCs (Table 3). Carpet with dust samples incubated at the Medium (75\%-80\% ERH) condition compared to carpet without dust samples incubated at the Medium (75\%-80\% ERH) condition were associated with probable
mVOCs, $\mathrm{C}_{3} \mathrm{H}_{4} \mathrm{H}^{+}$(propyne, FDR $\left.p=0.004\right), \mathrm{C}_{7} \mathrm{H}_{6} \mathrm{OH}^{+}$ (benzaldehyde, FDR $p=0.04), \mathrm{C}_{8} \mathrm{H}_{16} \mathrm{OH}^{+}$(1-octen-3-ol, FDR $p=0.0009$ ) and $\mathrm{C}_{3} \mathrm{H}_{8} \mathrm{OSH}^{+}$(2(methylmercapto)ethanol, FDR $p=0.03$ ) (Table S19). No associations were found when comparing dust embedded in carpet samples incubated at the Low ERH condition to carpet without dust incubated at the Low ERH condition.

The concentration of $\mathrm{CO}_{2}$ from the carpet with dust samples incubated at 95\% ERH was higher than the 
Table 3 The $\mathrm{m} / \mathrm{z}$ ratios that are associated with carpet with dust samples incubated at 95\% ERH when compared to carpet without dust samples incubated at 95\% ERH for 4 weeks utilizing the FDR adjustment.

\begin{tabular}{|c|c|c|c|c|}
\hline \multicolumn{5}{|c|}{$\mathrm{M} / \mathrm{z}$ ratios associated with carpet with dust samples at High (95\%) ERH } \\
\hline $\mathrm{m} / \mathrm{z}$ & Most likely formula & Compounds consistent with chemical formula & Unadjusted $P$-value & $\begin{array}{l}\text { Adjusted } \\
P \text {-value }\end{array}$ \\
\hline 49.028 & $\mathrm{CH}_{4} \mathrm{O}_{2} \mathrm{H}^{+}$ & Methanediol & 0.0003 & 0.003 \\
\hline 58.029 & $\mathrm{C}_{2} \mathrm{H}_{3} \mathrm{NOH}^{+}$ & Methyl Isocyanate & 0.003 & 0.01 \\
\hline 63.025 & $\mathrm{C}_{2} \mathrm{H}_{6} \mathrm{SH}^{+}$ & Dimethyl sulfide + Ethanethiol & 0.009 & 0.03 \\
\hline 74.024 & $\mathrm{C}_{2} \mathrm{H}_{3} \mathrm{NO}_{2} \mathrm{H}^{+}$ & Nitroethene & 0.007 & 0.02 \\
\hline 89.04 & $\mathrm{C}_{7} \mathrm{H}_{4} \mathrm{H}^{+}$ & Butadiynylallene & 0.0002 & 0.003 \\
\hline 91.947 & $\mathrm{C}_{2} \mathrm{HClS}+$ & Chloroacetylenethiol & 0.002 & 0.008 \\
\hline 93.036 & $\mathrm{C}_{3} \mathrm{H}_{8} \mathrm{SOH}^{+}$ & Methylmercaptoethanol & 0.008 & 0.03 \\
\hline 103.074 & $\mathrm{C}_{5} \mathrm{H}_{10} \mathrm{O}_{2} \mathrm{H}^{+}$ & Propyl Acetate + Valeric acid & 0.01 & 0.04 \\
\hline 115.092 & $\mathrm{C}_{7} \mathrm{H}_{11} \mathrm{FH}^{+}$ & Fluoronorbornane & 0.01 & 0.03 \\
\hline 117.955 & $\mathrm{C}_{3} \mathrm{H}_{4} \mathrm{~S}_{2} \mathrm{O}^{+}$ & Dithiolanone & 0.004 & 0.02 \\
\hline 118.903 & $\mathrm{CHCl}_{3} \mathrm{H}^{+}$ & Chloroform & 0.01 & 0.04 \\
\hline 120.066 & $\mathrm{C}_{4} \mathrm{H}_{9} \mathrm{NO}_{3} \mathrm{H}^{+}$ & Aminohydroxybutyric acid & $<.0001$ & 0.003 \\
\hline 121.955 & $\mathrm{C}_{3} \mathrm{HCl}_{2} \mathrm{NH}^{+}$ & Dichloroacrylonitrile & 0.0003 & 0.003 \\
\hline 124.047 & $\mathrm{C}_{3} \mathrm{H}_{9} \mathrm{NO}_{2} \mathrm{SH}^{+}$ & & 0.001 & 0.006 \\
\hline 124.12 & & & 0.005 & 0.02 \\
\hline 129.017 & $\mathrm{C}_{5} \mathrm{H}_{4} \mathrm{O} 4 \mathrm{H}^{+}$ & Hydroxyfuroic acid & $<.0001$ & 0.003 \\
\hline 130.091 & $\mathrm{C}_{6} \mathrm{H}_{11} \mathrm{NO}_{2} \mathrm{H}^{+}$ & Nitrocyclohexane & 0.002 & 0.01 \\
\hline 132.109 & $\mathrm{C}_{5} \mathrm{H}_{13} \mathrm{~N}_{3} \mathrm{OH}^{+}$ & Aminobutylurea & 0.009 & 0.03 \\
\hline 136.083 & $\mathrm{C}_{5} \mathrm{H}_{13} \mathrm{NSOH}^{+}$ & Methioninol & 0.006 & 0.02 \\
\hline 136.952 & $\mathrm{C}_{3} \mathrm{H}_{4} \mathrm{OSeH}^{+}$ & Oxopropaneselenal & 0.002 & 0.008 \\
\hline 137.131 & $\mathrm{C}_{10} \mathrm{H}_{16} \mathrm{H}^{+}$ & Monoterpenes & 0.0005 & 0.004 \\
\hline 137.959 & $\mathrm{C}_{3} \mathrm{H}_{5} \mathrm{OSeH}^{+}$ & Propeneselenenic acid & 0.0002 & 0.003 \\
\hline 138.062 & $\mathrm{C}_{4} \mathrm{H}_{11} \mathrm{NO}_{2} \mathrm{SH}^{+}$ & Tertbutylsulfonamide & 0.003 & 0.01 \\
\hline 142.123 & $\mathrm{C}_{8} \mathrm{H}_{15} \mathrm{NOH}^{+}$ & Cyclohexylacetamide & 0.005 & 0.02 \\
\hline 143.123 & ${ }^{13} \mathrm{CC}_{7} \mathrm{H}_{15} \mathrm{NOH}^{+}$ & ${ }^{13} \mathrm{C}$-cyclohexylacetamide & 0.002 & 0.008 \\
\hline 144.065 & $\mathrm{C}_{6} \mathrm{H}_{9} \mathrm{NO}_{3} \mathrm{H}^{+}$ & 2-Methoxyethyl cyanoacetate & 0.0001 & 0.003 \\
\hline 149.095 & $\mathrm{C}_{10} \mathrm{H}_{12} \mathrm{OH}^{+}$ & Estragole & 0.01 & 0.04 \\
\hline 153.055 & $\mathrm{CH}_{8} \mathrm{O}_{3} \mathrm{H}^{+}$ & Methyl hydroxybenzoate & 0.0006 & 0.004 \\
\hline 153.126 & $\mathrm{C}_{10} \mathrm{H}_{16} \mathrm{OH}^{+}$ & Monoterpene carbonyls (e.g. camphor) & 0.0006 & 0.004 \\
\hline 158.089 & $\mathrm{C}_{6} \mathrm{H}_{11} \mathrm{~N}_{3} \mathrm{O}_{2} \mathrm{H}^{+}$ & & 0.0007 & 0.004 \\
\hline 158.96 & & & 0.002 & 0.008 \\
\hline 159.137 & $\mathrm{C}_{9} \mathrm{H}_{18} \mathrm{O}_{2} \mathrm{H}^{+}$ & Nonanoic Acid & 0.01 & 0.04 \\
\hline 161.132 & $\mathrm{C}_{12} \mathrm{H}_{16} \mathrm{H}^{+}$ & Benzene & 0.01 & 0.04 \\
\hline 162.908 & & & 0.002 & 0.01 \\
\hline 165.092 & $\mathrm{C}_{10} \mathrm{H}_{12} \mathrm{O}_{2} \mathrm{H}^{+}$ & Phenethyl acetate & 0.003 & 0.01 \\
\hline 168.184 & & & $<.0001$ & 0.003 \\
\hline 169.122 & $\mathrm{C}_{10} \mathrm{H}_{16} \mathrm{O}_{2} \mathrm{H}^{+}$ & Geranic acid, Massoia lactone, Jasmine lactone & 0.003 & 0.01 \\
\hline 171.117 & $\mathrm{C}_{13} \mathrm{H}_{14} \mathrm{H}^{+}$ & IsopropyInaphthalene & 0.002 & 0.008 \\
\hline 177.009 & & & 0.004 & 0.02 \\
\hline 178.015 & & & 0.002 & 0.01 \\
\hline 178.06 & $\mathrm{C}_{6} \mathrm{H}_{13} \mathrm{~N}_{2} \mathrm{~S}_{2} \mathrm{H}^{+}$ & & $<.0001$ & 0.003 \\
\hline 182.156 & $\mathrm{C}_{11} \mathrm{H}_{19} \mathrm{ONH}^{+}$ & N-ethyl trans-2-cis-6-nonadienamide & 0.0003 & 0.003 \\
\hline
\end{tabular}


Table 3 The $\mathrm{m} / \mathrm{z}$ ratios that are associated with carpet with dust samples incubated at 95\% ERH when compared to carpet without dust samples incubated at 95\% ERH for 4 weeks utilizing the FDR adjustment. (Continued)

\begin{tabular}{|c|c|c|c|c|}
\hline \multicolumn{5}{|c|}{$\mathrm{M} / \mathrm{z}$ ratios associated with carpet with dust samples at High (95\%) ERH } \\
\hline $\mathrm{m} / \mathrm{z}$ & Most likely formula & Compounds consistent with chemical formula & Unadjusted $P$-value & $\begin{array}{l}\text { Adjusted } \\
P \text {-value }\end{array}$ \\
\hline 185.189 & $\mathrm{C}_{12} \mathrm{H}_{24} \mathrm{OH}^{+}$ & Methylundecanal & 0.01 & 0.03 \\
\hline 189.162 & $\mathrm{C}_{9} \mathrm{H}_{20} \mathrm{~N}_{2} \mathrm{O}_{2} \mathrm{H}^{+}$ & Diaminononanoic acid & 0.006 & 0.02 \\
\hline 195.135 & $\mathrm{C}_{7} \mathrm{H}_{18} \mathrm{O}_{4} \mathrm{~N}_{2} \mathrm{H}^{+}$ & 1-[2-(2-Hydroxyethylamino)ethylamino]propane-1,2,3-trio & 0.0004 & 0.003 \\
\hline 200.206 & $\mathrm{C}_{12} \mathrm{H}_{25} \mathrm{NOH}^{+}$ & Dodecanamide & $<.0001$ & 0.003 \\
\hline 201.114 & $\mathrm{C}_{10} \mathrm{H}_{16} \mathrm{O}_{4} \mathrm{H}^{+}$ & Camphoric Acid & 0.005 & 0.02 \\
\hline 204.186 & $\mathrm{C}_{8} \mathrm{H}_{21} \mathrm{~N}_{3} \mathrm{OH}^{+}$ & & 0.0004 & 0.003 \\
\hline 214.167 & $\mathrm{C}_{9} \mathrm{H}_{19} \mathrm{~N}_{5} \mathrm{OH}^{+}$ & & 0.007 & 0.02 \\
\hline 219.177 & $\mathrm{C}_{12} \mathrm{H}_{26} \mathrm{OSH}^{+}$ & Dihexyl sulfoxide, 12-Mercapto-1-dodecanol & 0.003 & 0.01 \\
\hline 222.159 & $\mathrm{C}_{12} \mathrm{H}_{19} \mathrm{~N}_{3} \mathrm{OH}^{+}$ & & 0.0001 & 0.003 \\
\hline 238.872 & & & 0.01 & 0.03 \\
\hline 247.241 & $\mathrm{C}_{18} \mathrm{H}_{30} \mathrm{H}^{+}$ & Dodecylbenzene & $<.0001$ & 0.003 \\
\hline 251.271 & $\mathrm{C}_{18} \mathrm{H}_{34} \mathrm{H}^{+}$ & 1-Octadecyne & 0.0005 & 0.004 \\
\hline 262.262 & $\mathrm{C}_{19} \mathrm{H}_{33} \mathrm{H}^{+} / \mathrm{C}_{12} \mathrm{H}_{31} \mathrm{~N}_{5} \mathrm{OH}^{+}$ & & 0.0002 & 0.003 \\
\hline 267.008 & $\mathrm{C}_{11} \mathrm{H}_{10} \mathrm{~N}_{2} \mathrm{~S}_{3} \mathrm{H}^{+} / \mathrm{C}_{10} \mathrm{H}_{6} \mathrm{~N}_{2} \mathrm{O}_{5} \mathrm{SH}^{+}$ & 5-[(1Z,2E)-3-(5-Nitro-2-furanyl)-2-propenylidene]thiazolidine-2,4-dione & 0.005 & 0.02 \\
\hline 268.983 & $\mathrm{C}_{10} \mathrm{H}_{8} \mathrm{~N}_{2} \mathrm{O}_{2} \mathrm{SeH}^{+}$ & & 0.008 & 0.03 \\
\hline 283.266 & $\mathrm{C}_{18} \mathrm{H}_{34} \mathrm{O}_{2} \mathrm{H}^{+}$ & Oleic Acid, Elaidic Acid & $<.0001$ & 0.003 \\
\hline 298.085 & & & 0.0003 & 0.003 \\
\hline 300.065 & $\mathrm{C}_{14} \mathrm{H}_{10} \mathrm{ClN}_{5} \mathrm{OH}^{+}$ & & 0.007 & 0.02 \\
\hline 301.289 & $\mathrm{C}_{22} \mathrm{H}_{36} \mathrm{H}^{+}$ & & $<.0001$ & 0.003 \\
\hline 317.079 & & & $<.0001$ & 0.003 \\
\hline 375.081 & & & 0.0006 & 0.004 \\
\hline 390.117 & & & $<.0001$ & 0.003 \\
\hline 442.126 & & & 0.0002 & 0.003 \\
\hline 444.123 & & & 0.002 & 0.01 \\
\hline 445.107 & & & 0.0001 & 0.003 \\
\hline 447.095 & & & 0.004 & 0.02 \\
\hline 461.136 & & & 0.0007 & 0.004 \\
\hline 464.125 & & & 0.0002 & 0.003 \\
\hline
\end{tabular}

concentration from the carpet without dust incubated at the same ERH (Figure S17). The average $\mathrm{CO}_{2}$ concentration at 95\% ERH for carpet with dust samples was 5.92 \pm $1.15 \mathrm{mg} \mathrm{hr}^{-1} \mathrm{~kg}^{-1}$ while the average for carpet without dust at $95 \% \mathrm{ERH}$ was $2.55 \pm 1.22 \mathrm{mg} \mathrm{hr}^{-1} \mathrm{~kg}^{-1} \cdot \mathrm{CO}_{2}$ data at other ERH conditions (65\%, 70\% and 75\%) did not reveal differences in concentration of $\mathrm{CO}_{2}$ from carpet with dust and carpet without dust (Figure S18).

The collection location samples consisted of carpet without dust, carpet with dust, dust only samples, drywall only and inoculated drywall collected from $\mathrm{CA}, \mathrm{OH}$, and FL that were incubated at either $50 \%$ or $85 \% \mathrm{ERH}$ consistently for two weeks. As these samples and were sampled on the PTR-TOF-MS for $\sim 3$ minutes using a "snap-shot" approach they cannot be used to report quantitative results. Concentrations from this data therefore provide a semiquantitative look at changes in compositional signatures. Four compounds that were associated with carpet with dust at 95\% ERH from the moisture availability samples, $\mathrm{C}_{2} \mathrm{H}_{6} \mathrm{SH}^{+}$(dimethyl sulfide + ethanethiol), $\quad \mathrm{CHCl}_{3} \mathrm{H}^{+}$(chloroform), $\mathrm{C}_{10} \mathrm{H}_{16} \mathrm{H}^{+}$ (monoterpenes) and $\mathrm{C}_{10} \mathrm{H}_{16} \mathrm{O}_{4} \mathrm{H}^{+}$(camphoric acid,) were chosen to analyze in the collection location samples. No site differences for these compounds were found. The emissions profile of samples of carpet with dust from the different locations were visually similar (Figure S19). 


\section{Microbial and chemical diversity}

Increased equilibrium relative humidity was associated with decreased fungal species diversity, the number of different fungal species found within a given microbiome (Figure S20, linear regression $p=0.005, R^{2}=0.82$ ). For instance, only 92 fungal species were measured in the $95 \%$ ERH CA carpet and dust samples, while 501 fungal species were found in the 50\% ERH CA carpet and dust samples. The data for carpet with dust samples were provided for the same 752 chemical VOC ions, however the abundance varied by six orders of magnitude and certain compounds were clearly associated with different ERH conditions. 38 ions were more associated with the High ERH condition when compared to both the Medium and Low ERH condition while 108 ions were more associated with Medium ERH compared to Low and High ERH and 103 ions were more associated with Low ERH compared to High and Medium ERH in the carpet with dust moisture samples.

\section{Discussion}

Carpet with dust and drywall have different equilibrium relative humidity requirements to support fungal growth. Collection site contributed to microbial species composition, while type of substrate (carpet, dust, drywall) contributed to the release of VOCs and mVOCs. The release of VOC emissions was mainly due to the materials themselves; however certain compounds were determined as mVOCs at higher moisture conditions (>85\% ERH).

\section{Excess moisture and microbial changes}

Excess moisture altered both the amount of microbial growth and species type in the different building materials. In this study, microbial communities in carpet began to grow between $75 \%$ and $80 \% \mathrm{ERH}$ and in drywall began to grow above $85 \% \mathrm{ERH}$. These findings are generally consistent with other studies $[18,20,55]$ and highlight that the threshold relative humidity values to keep a home "dry" are localized. For instance, microbial communities on drywall in a bathroom are likely to be less responsive to episodic periods of high humidity than those in carpet in a living room. This emphasizes the need to include both dust and carpet in addition to drywall as they are both important reservoirs for human exposure [56]. Additionally, this reiterates concerns about the presence of carpet and similar materials in damp areas $[57,58]$.

Interestingly, carpet type and paint type on drywall did not strongly influence microbial species composition, while collection site did. There was no statistical difference when comparing the microbial communities in carpet A to those of carpet B across site location of dust origin. Both carpets were made of nylon carpet fibers, however carpet A was cut pile without any antimicrobial treatments and carpet B was loop pile with an antimicrobial treatment. Fiber type is known to influence the microbial composition in carpets [13] and may have influenced the similarity within microbial communities in these experiments. Collection site was associated with species composition when comparing samples of dust, carpet, and drywall from $\mathrm{CA}, \mathrm{OH}$, and FL. One factor that might influence this is geographic location [59]. The Chase (2016) study collected samples from different geographic locations over a period of one year, while our study utilized dust samples taken from multiple homes in different geographic locations at one time point. Previous work has shown that individual homes within a smaller geographic region of Ohio vary in taxonomic composition in response to excess moisture [19]. Because we sampled across multiple homes in a geographic location, we attribute variation across to be driven by geographic differences, but there may be additional variation due to home characteristics.

Despite this variation, the genera and species that we detected, such as Penicillium, Aspergillus, Cladosporium, and Wallemia, are common in the indoor environment [60-64]. The dependency of microbial communities on home of origin increases the challenge of identifying microbial indicators for dampness that are superior to visual inspection and detection of moldy odor as these indicators are qualitative at most [10].

\section{Understanding the emissions profile}

Under elevated relative humidity conditions, the majority of the emissions from these samples were likely from the substrate: carpet, dust, and drywall, and not from growing microorganisms and their metabolic processes. Building materials have been recognized as a strong source of VOCs with sizeable emissions from carpets, textile materials, adhesives, wallboards, sealants, and urethane coatings [65]. Emissions of VOCs are highly dependent on substrate, with one study determining $70 \%$ of the total indoor VOCs attributed to different indoor sources such as household products, combustion processes, deodorizers and building materials [66]. $\mathrm{C}_{5} \mathrm{H}_{10} \mathrm{H}^{+}$(cyclopentane/pentene), $\mathrm{C}_{4} \mathrm{H}_{8} \mathrm{H}^{+}$, (butanol/butene) and $\mathrm{C}_{3} \mathrm{H}_{4} \mathrm{H}^{+}$(propyne) were abundantly emitted from samples of carpet without dust at 95\% ERH, while $\mathrm{CH}_{2} \mathrm{O}_{3} \mathrm{H}^{+}$(performic acid), $\mathrm{C}_{2} \mathrm{H}_{5} \mathrm{NO}_{2} \mathrm{H}^{+}$(methyl carbamate), $\mathrm{C}_{6} \mathrm{H}_{6} \mathrm{O}_{2} \mathrm{H}^{+}$(2-acetylfuran), $\mathrm{C}_{6} \mathrm{H}_{6} \mathrm{H}^{+}$(benzene), and $\mathrm{C}_{3} \mathrm{H}_{6} \mathrm{H}^{+}$(propene) were associated with autoclaved drywall at 95\% ERH. These VOCs are all commonly associated with building materials [67]. Formaldehyde and acetaldehyde were also emitted from the carpet samples. One study found that carpet is the most important factor contributing to formaldehyde and acetaldehyde concentrations indoors [68] 
We observed a lower emission factor from carpet with dust $\left(500-2000 \mu \mathrm{g} \mathrm{hr}^{-1} \mathrm{~g}^{-1}\right.$ carpet) than carpet without dust (800 - $3000 \mu \mathrm{g} \mathrm{hr} \mathrm{gg}^{-1}$ carpet). Other studies have observed dust as a sink for semi-volatile organic compounds $[69,70]$. We hypothesize that dust itself absorbs volatile emissions from the carpet, although further study is needed.

\section{VOCs with abiotic and biotic sources}

Many compounds in this study were determined to have both biological and non-biological potential sources, a common obstacle when studying volatile chemicals in complex environments $[71,72]$. The compound $\mathrm{C}_{6} \mathrm{H}_{6} \mathrm{OH}^{+}, \mathrm{m} / \mathrm{z}$ 95.0468, was identified as phenol, and may be emitted from both a microbial and carpet source. Phenol is involved in the process of generating two intermediate products that are used in nylon production: caprolactam and bisphenol [73]. Phenol is also emitted by soil bacteria as a nematocidal volatile and by endophytic microorganisms in a symbiotic relationship with certain plant species $[74,75]$. Other detected VOCs including acetic acid and acetaldehyde have both anthropogenic and microbial sources [37, 76-78]. It is difficult to distinguish, even at the high ERH where increased microbial growth was observed, the individual sources of the emissions from carpet, drywall, dust, or microbes. Delineating compounds in a complex system such as carpet is difficult without use of multivariate approaches which can determine the exact factor loadings for each compound. Another approach may be separately analyzing each component of a material to determine which compounds are emitted from each component. Future studies of isotopically labeled compounds could also elucidate sources.

Despite the difficulty in explicitly separating the building material emissions from the microbial emissions, utilizing the FDR analysis and the differences in observed chemical families at each ERH suggests that microbial emissions contribute to the overall VOC fingerprint. For homes without moisture damage, microbial emissions may not be an abundant source of emissions indoors relative to other sources. However, they are still an important part of the overall emissions profile, especially in regard to their reactivity, health concerns, and role as an odorant and irritant [11, 79, 80]. Limonene, a compound that has been identified as a common indoor mVOC, reacts quickly with ozone creating products that are active contributors to indoor chemistry [81, 82]. The products of the ozone-limonene reaction include several allergens, some of which pose a greater health concern than limonene itself [83]. Stable mVOCs like 1-butanol are also relevant to health concerns, as experiments where bronchoalveolar lavage cells were incubated with 1-butaonl lead to increased histamine production $[84,85]$. mVOCs also play a substantial role in odor irritation indoors and the overall comfort of residents, as the odor threshold of VOCs is typically one to four orders of magnitude lower than that for irritation of the airways [79]. It is possible that longer incubation times at increased moisture conditions may have resulted in the microbial emissions dominating the emissions profile.

\section{Relationship between abiotic factors and VOCs}

The relationship between VOCs and relative humidity is another factor that complicates interpretation of the overall emissions profile. The relationship between microbial growth and relative humidity is fairly well studied, with elevated relative humidity leading to more growth in microbial communities $[18,19]$. One possibility is that as microbial growth increases so does the release of mVOCs in the indoor environment [61]. However, it is also possible that the mVOC profiles change, rather than increasing the total abundance increases, as the microbes transition through their life cycle $[12,86]$. These ideas are not mutually exclusive. That is, certain mVOCS may be released at elevated relative humidity during primary metabolism, while others may be released when growth has ceased. The mVOC abundance is expected to change proportionally with the changes in microbial density that may span orders of magnitude [35].

Increasing relative humidity can either increase or decrease the emissions of VOCs and the sink effect of the material [87]. The impact of relative humidity level is dependent on both the material and the specific VOC, as multiple phenomena such as diffusion, adsorption, and condensation may alter results [88] and lead to nonlinear emissions in response to moisture [87]. Indeed, in our study, the relative humidity level at which a compound had the highest abundance was dependent on processes such as the specific compound and type of sample (e.g. carpet without dust, carpet with dust) that simultaneously affected the emissions profile. For example, polar compounds such as acetate and acetic acid had higher abundance of emissions at lower ERHs (50\%, $65 \%$ ) then compared to 95\% ERH. Wolkoff (1998) observed similar results and attributed it to desorption of specific compounds to the water vapor at high relative humidity. However, this result does not extend to all polar compounds as seen by Markowicz and Larsson (2015), which further emphasizes the compound specificity in regard to moisture.

New technology allows us to address an expanding set of questions pertaining to mVOCs [29, 89-91]. mVOC emissions are not constant and can be affected by substrate type, temperature, $\mathrm{pH}$, moisture content, and potentially other factors, many of which are abiotic factors 
that change frequently in an indoor environment [92, 93]. This reality highlights the complexity in attempting to determine a single $\mathrm{mVOC}$ as an indicator of fungal growth indoors. We suggest that future work should not focus solely on separating microbial emissions from anthropogenic emissions, as mVOCs are inherently connected to their environment which is dominated by anthropogenic factors. Rather, the focus should be on characterizing the attributes of an overall emissions profile with a microbial contribution.

\section{Limitations}

This research was conducted in a laboratory setting utilizing glass incubation chambers that do not fully represent the indoor environment. The indoor environment consists of varying factors that may disrupt changes in temperature and humidity that may not be represented through our chamber experiments. The major differences are the static incubation timescales where $\mathrm{RH}$ was not cycled and was conducted only for a relatively short period (two to four weeks) compared to real indoor environments. However, findings from this study emphasize the importance of maintaining proper relative humidity in homes to limit microbial growth, VOC, and mVOC emissions.

Multiple compounds with different structures may be associated with some chemical formulas. The compound specified in parentheses corresponds to the isomer that was most consistent with a formula based on relevant properties of the compound such as vapor pressure, boiling point, and knowledge of chemical composition of the source. However, in case of larger molecules or multiisomeric formulas, we cannot conclusively say that a certain chemical isomer was emitted from these materials, in which case we refer just to the chemical formula. Due to a technical issue with the PTR-TOF-MS (drift module failure) which occurred on the day of $85 \%$ ERH sample collection, emissions data collected from these samples were not used in the analysis.

All samples of carpet and drywall were initially autoclaved and baked overnight at $30^{\circ} \mathrm{C}$ to create "sterile non-microbial" conditions to be used as control samples. Autoclaving the carpet may have impacted thermally unstable compounds accelerating degradation and other transformations within the materials. Vacuumed particles on filters and swabs collected from samples of only carpet without dust and drywall (no inoculation) did amplify on $\mathrm{qPCR}$, with carpet without dust quantities ranging from $10^{2}-10^{3}$ spore equivalents $/ \mathrm{mg}$ filter dust and autoclaved drywall ranging from $10^{3}-10^{5}$ spore equivalents $/ \mathrm{cm}^{2}$ drywall. When sequenced on the Illumina MiSeq, however, these samples were removed during quality filtering and no species were determined. Dust irradiated with a $10 \mathrm{kGy}$ electron beam was plated on growth media and some microbial colonies were observed, though much less growth occurred when compared to that of the non-ionized dust. Therefore, these samples may have also had a minor contribution from residual microbial communities.

\section{Conclusions}

Moisture plays an important role in regulating microbial growth and VOC/mVOCs emissions. This study demonstrates the importance of comparing indoor materials such as carpet and drywall as each material represents a distinct component of indoor chemical and microbial exposures. Growth in dust is also distinctly different than that of growth on drywall as we determined that fungal growth in dust requires a lower level of moisture than that of drywall. Understanding resuspension rates of dust in homes and clear knowledge of the chemical compounds from dust at humidity conditions above $75 \%$ are needed. Proper humidity conditions must also be maintained as different emissions may be released under different moisture conditions. We found that moisture plays a key role in the release of both VOC and mVOCs, though the relationship is nonlinear.

These results have broad implications for managing growth and emissions in the indoor environment to ensure proper human health. Current detection of mold growth indoors is constrained to visual inspection or moldy odor detection as we lack a quantitative means of mold measurement. Utilizing mVOC emissions in mold detection may have important implications for the future of mold level detection in housing. Continued work is necessary to determine mVOCs from common fungal species indoors. However, this may be difficult as fungal species in homes vary by home environment and collection site. Ultimately these results highlight the necessity for continued work and complex relationships between moisture, microbes, and chemicals in the indoor environment.

\section{Supplementary Information}

The online version contains supplementary material available at https://doi. org/10.1186/s40168-021-01158-y.

\section{Additional file 1. \\ Additional file 2}

\section{Acknowledgements}

The research carried out to produce this manuscript was supported by the Alfred P. Sloan Foundation grant, G-2018-11240. We would like to thank The Ohio Supercomputer Center who provided a platform for data analysis.

Availability of data and material

The datasets generated and/or analyzed during the current study are available in the European Nucleotide Archive under accession number PRJEB41403. 


\section{Authors' contributions}

$\mathrm{SH}$ carried out the experiments, analyzed and compiled data, and wrote the manuscript. EH analyzed the chemical data and wrote the chemical components of the manuscript. KM collected the chemical data. PM conceived of the idea for chemical experiments, oversaw these experiments and data analysis, and edited the manuscript. AG contributed to the conception of the project. KD and RA conceived of the biological experiments, oversaw these experiments and data analysis, and edited the manuscript. All authors read and approved the final manuscript.

\section{Funding}

Funds to support this work were provided by the Alfred P. Sloan Foundation (grant G-2018-11240).

\section{Declarations}

Ethics approval and consent to participate

Not applicable.

\section{Consent for publication}

Not applicable.

\section{Competing interests}

The authors declare that they have no competing interests

\section{Author details}

'Department of Civil \& Mineral Engineering, University of Toronto, Toronto, Ontario M5S 1A4, Canada. ${ }^{2}$ Department of Civil, Architectural and Environmental Engineering, University of Texas at Austin, Austin, TX 78712, USA. ${ }^{3}$ School of Chemistry, The University of Edinburgh, Edinburgh EH9 3FJ, UK. ${ }^{4}$ Department of Environmental Science, Policy and Management, University of California, Berkeley, CA 94720, USA. ${ }^{5}$ Department of Plant and Microbial Biology, University of California, Berkeley, CA 94720, USA. ${ }^{6}$ Department of Civil, Environmental \& Geodetic Engineering, College of Engineering, Ohio State University, Columbus, OH 43210, USA. 'Division of Environmental Health Sciences, College of Public Health, Ohio State University, Columbus, OH 43210, USA. ${ }^{8}$ Sustainability Institute, Ohio State University, Columbus, OH 43210, USA. ${ }^{9}$ Department of Civil, Environmental \& Geodetic Engineering, Environmental Health Sciences, Ohio State University, 470 Hitchcock Hall, 2070 Neil Ave, Columbus, OH 43210, USA.

\section{Received: 15 February 2021 Accepted: 27 August 2021}

\section{Published online: 19 October 2021}

\section{References}

1. Klepeis NE, Nelson WC, Ott WR, Robinson JP, Tsang AM, Switzer P, et al. The National Human Activity Pattern Survey (NHAPS): a resource for assessing exposure to environmental pollutants. J Expo Anal Environ Epidemiol. 2001; 11(3):231-52. https://doi.org/10.1038/sj.jea.7500165.

2. World Health Organization. WHO guidelines for indoor air quality: dampness and mold [Internet]. WHO Guidel. Indoor Air Qual. 2009. Available from: www.euro.who.int

3. Mendell MJ, Mirer AG, Cheung K, Tong M, Douwes J. Respiratory and allergic health effects of dampness, mold, and dampness-related agents: A review of the epidemiologic evidence [Internet]. Environ. Health Perspect. National Institute of Environmental Health Sciences; 2011 [cited $2020 \mathrm{Jul}$ 31]. p. 748-56. Available from: https://ehp.niehs.nih.gov/doi/https://doi.org/1 0.1289/ehp. 1002410

4. Fisk WJ, Lei-Gomez Q. Mendell MJ. Meta-analyses of the associations of respiratory health effects with dampness and mold in homes. Indoor Air. 2007;17(4):284-96. https://doi.org/10.1111/j.1600-0668.2007.00475.x.

5. Jones R, Recer GM, Hwang SA, Lin S. Association between indoor mold and asthma among children in Buffalo, New York. Indoor Air. 2011;21:156-164. https://doi.org/10.1111/j.1600-0668.2010.00692.x.

6. Hernberg S, Sripaiboonkij P, Quansah R, JJK J, Jaakkola MS. Lung function is reduced among subjects with asthma exposed to mold odor. Chest: American College of Chest Physicians; 2014. p. e28-9.

7. Lorentzen JC, Juran SA, Nilsson M, Nordin S, Johanson G. Chloroanisoles may explain mold odor and represent a major indoor environment problem in Sweden. Indoor Air. 2016;26(2):207-18. https://doi.org/10.1111/ ina.12207.
8. Shorter C, Crane J, Pierse N, Barnes P, Kang J, Wickens K, et al. Indoor visible mold and mold odor are associated with new-onset childhood wheeze in a dose-dependent manner. Indoor Air. 2018;28(1):6-15. https://doi.org/1 0.1111/ina.12413

9. Kim JL, Elfman L, Mi Y, Wieslander G, Smedje G, Norbäck D. Indoor molds, bacteria, microbial volatile organic compounds and plasticizers in schools Associations with asthma and respiratory symptoms in pupils. Indoor Air. 2007:17:153-63.

10. Mendell MJ, Adams RI. The challenge for microbial measurements in buildings. Indoor Air. 2019;29(4):523-6. https://doi.org/10.1111/ina.12550.

11. Korpi A, Järnberg J, Pasanen AL. Microbial volatile organic compounds. Crit Rev Toxicol. 2009;39(2):139-93. https://doi.org/10.1080/10408440802291497.

12. Berry DR. Products of primary metabolic pathways. In: Physiol Ind fungi. Oxford: Blackwell Scientific Publications; 1988. p. 130-60.

13. Nastasi $N$, Haines $S R, X u L$, da Silva $H$, Divjan $A$, Barnes MA, et al. Morphology and quantification of fungal growth in residential dust and carpets. Build Environ. 2020;174:106774.

14. US EPA. Mold Course Chapter 2: 2017 [cited 2021 Jan 6]; Available from: https://www.epa.gov/mold/mold-course-chapter-1

15. US EPA. Mold Course Chapter 2: Why and Where Mold Grows [Internet]. 2017 [cited 2019 Dec 18]. Available from: https://www.epa.gov/mold/moldcourse-chapter-2

16. Tariku F, Kumaran K, Fazio P. Determination of indoor humidity profile using a whole-building hygrothermal model. Build Simul. 2011;4:61-78. https://doi. org/10.1007/s12273-011-0031-x

17. Tariku F, Kumaran K, Fazio P. Transient model for coupled heat, air and moisture transfer through multilayered porous media. Int J Heat Mass Transf. 2010;53(15-16):3035-44. https://doi.org/10.1016/j.j.jheatmasstransfer.2 010.03.024.

18. Dannemiller KC, Weschler CJ, Peccia J. Fungal and bacterial growth in floor dust at elevated relative humidity levels. Indoor Air. 2017;27(2):354-63. https://doi.org/10.1111/ina.12313.

19. Haines SR, Siegel JA, Dannemiller KC. Modeling microbial growth in carpet dust exposed to diurnal variations in relative humidity using the "Time-ofWetness" framework. Indoor Air; 2020;30:978-992. [cited 2021 Jan 26] Available from: https://onlinelibrary.wiley.com/doi/abs/https://doi.org/1 $0.1111 /$ ina. 12686

20. Adan O, Samson R. Fundamentals of mold growth in indoor environments and strategies for healthy living. Wageningen: Wageningen Academic Publishers; 2011. https://doi.org/10.3920/978-90-8686-722-6.

21. Adan O. On the fungal defacement of interior finishes. Eindhoven University of Technology. Eindhoven, Netherlands; 1994. https://doi.org/10.6100/R427806.

22. Brennan T, Cummings JB, Lstiburek J. Unplanned airflows \& moisture problems. ASHRAE J. 2002:44:44 46+48+50.

23. Kormos D, Dannemiller K, May AA. Modeling Water Uptake of Dust in the Indoor Environment Undergraduate Research Distinction in Environmental Engineering Thesis. The Ohio State University, Columbus, Ohio, USA; 2019. https://kb.osu.edu/handle/1811/87417

24. Ibrahim S, Romanias MN, Alleman LY, Zeineddine MN, Angeli GK, Trikalitis $\mathrm{PN}$, et al. Water interaction with mineral dust aerosol: particle size and hygroscopic properties of dust. ACS Earth Sp Chem. 2018;2:376-86.

25. Herich H, Tritscher T, Wiacek A, Gysel M, Weingartner E, Lohmann U, et al. Water uptake of clay and desert dust aerosol particles at sub- and supersaturated water vapor conditions. Phys Chem Chem Phys. 2009;11:7804-9.

26. Schleibinger $H$, Laußmann D, Brattig C, Mangler M, Eis D, Ruden H. Emission patterns and emission rates of MVOC and the possibility for predicting hidden mold damage?. Indoor Air Suppl. 2005;5(s9):98-104.

27. Misztal PK, Lymperopoulou DS, Adams Rl, Scott RA, Lindow SE, Bruns T, et al. Emission factors of microbial volatile organic compounds from environmental bacteria and fungi. Environ Sci Technol. 2018;52(15):82728282. https://doi.org/10.1021/acs.est.8b00806.

28. Fischer G, Schwalbe R, Möller M, Ostrowski R, Dott W. Species-specific production of microbial volatile organic compounds (MVOC) by airborne fungi from a compost facility. Chemosphere. Pergamon. 1999;39(5):795-810. https://doi.org/10.1016/S0045-6535(99)00015-6.

29. Kalalian C, Abis L, Depoorter A, Lunardelli B, Perrier S, George C. Influence of indoor chemistry on the emission of mVOCs from Aspergillus niger molds. Sci Total Environ. 2020;741:140148.

30. Batterman SA. Sampling and analysis of biological volatile organic compounds. Bioaerosols. 1995:249-68. https://doi.org/10.1201/9781003 070078-12. 
31. Wheatley RE. The consequences of volatile organic compound mediated bacterial and fungal interactions. Antonie van Leeuwenhoek. 2002;81:35764. https://doi.org/10.1023/A:1020592802234.

32. Insam H, Seewald MSA. Volatile organic compounds (VOCs) in soils. Biol. Fertil. Soils. 2010;46(3):199-213. https://doi.org/10.1007/s00374-010-0442-3.

33. Leung $M H Y$, Lee $\mathrm{PKH}$. The roles of the outdoors and occupants in contributing to a potential pan-microbiome of the built environment: A review. Microbiome. 2016;4(21):1-15. https://doi.org/10.1186/s40168-016-0165-2.

34. Adams RI, Miletto M, Taylor JW, Bruns TD. Dispersal in microbes: Fungi in indoor air are dominated by outdoor air and show dispersal limitation at short distances. ISME J. 2013;7:1262-73. https://doi.org/10.1038/ismej.2013.28.

35. Dannemiller KC, Gent JF, Leaderer BP, Peccia J. Influence of housing characteristics on bacterial and fungal communities in homes of asthmatic children. Indoor Air. 2016;26(2):179-92. https://doi.org/10.1111/ina.12205.

36. Yu C, Crump D. A review of the emission of VOCs from polymeric materials used in buildings. Build Environ. 1998;33(6):357-74. https://doi.org/10.1016/ S0360-1323(97)00055-3.

37. Schaeffer VH, Bhooshan B, Chen SB, Sonenthal JS, Hodgson AJ. Characterization of Volatile Organic Chemical Emissions From Carpet Cushions. J Air Waste Manag Assoc. 1996;46(9):813-20. https://doi.org/10.1 080/10473289.1996.10467516.

38. Katsoyiannis A, Leva P, Kotzias D. VOC and carbonyl emissions from carpets: A comparative study using four types of environmental chambers. J Hazard Mater. 2008;152(2):669-76. https://doi.org/10.1016/j.jhazmat.2007.07.058.

39. Campagnolo D, Saraga DE, Cattaneo A, Spinazzè A, Mandin C, Mabilia R, et al. VOCs and aldehydes source identification in European office buildings - The OFFICAIR study. Build Environ. 2017;115:18-24. https://doi.org/10.1016/ j.buildenv.2017.01.009.

40. Lee K, Choi JH, Lee S, Park HJ, Oh YJ, Kim GB, et al. Indoor levels of volatile organic compounds and formaldehyde from emission sources at elderly care centers in Korea. Larcombe A, editor. PLoS One.; 2018;13:e0197495.

41. Andersen I, Lundqvist GR, Mølhave L. Indoor air pollution due to chipboard used as a construction material. Atmos Environ. 1975;9(12):1121-7. https:// doi.org/10.1016/0004-6981(75)90188-2.

42. Lin CC, Yu KP, Zhao P, Whei-May LG. Evaluation of impact factors on VOC emissions and concentrations from wooden flooring based on chamber tests. Build Environ. 2009;44(3):525-33. https://doi.org/10.1016/j.buildenv.2 008.04.015.

43. Wolkoff P. Impact of air velocity, temperature, humidity, and air on longterm VOC emissions from building products. Atmos Environ. 1998;32(14-15): 2659-68. https://doi.org/10.1016/S1352-2310(97)00402-0.

44. van Netten C, Shirtliffe C, Svec J. Temperature and humidity dependence of formaldehyde release from selected building materials. Bull Environ Contam Toxicol. 1989;42(4):558-65. https://doi.org/10.1007/BF01700238.

45. Dedesko S, Siegel JA. Moisture parameters and fungal communities associated with gypsum drywall in buildings. Microbiome. 2015;3:71 [cited 2019 Dec 6] Available from: http://www.microbiomejournal.com/ content/3/1/71.

46. Jordan A, Haidacher S, Hanel G, Hartungen E, Märk L, Seehauser H, et al. A high resolution and high sensitivity proton-transfer-reaction time-of-flight mass spectrometer (PTR-TOF-MS). Int J Mass Spectrom. 2009;286(2-3):122-8. https://doi.org/10.1016/j.ijms.2009.07.005.

47. Adams Rl, Lymperopoulou DS, Misztal PK, De Cassia Pessotti R, Behie SW, Tian Y, et al. Microbes and associated soluble and volatile chemicals on periodically wet household surfaces. Microbiome. 2017;5(1):128. https://doi. org/10.1186/s40168-017-0347-6

48. Tang X, Misztal PK, Nazaroff WW, Goldstein AH. Volatile organic compound emissions from humans indoors. Environ Sci Technol. 2016;50(23):12686-94. https://doi.org/10.1021/acs.est.6b04415.

49. Holzinger R. PTRwid: A new widget tool for processing PTR-TOF-MS data. Atmos Meas Tech. 2015;8(9):3903-22. https://doi.org/10.5194/amt-8-3903-2015.

50. Mathworks. MATLAB - Mathworks - MATLAB \& Simulink [Internet]. WwW. Mathworks.Com. 2016 [cited 2020 Oct 20]. p. 1. Available from: https://www. mathworks.com/products/matlab.htm

51. Benjamini Y, Hochberg Y. Controlling the False Discovery Rate: A Practical and Powerful Approach to Multiple Testing. J R Stat Soc Ser B. 1995;57(1): 289-300. https://doi.org/10.1111/j.2517-6161.1995.tb02031.x.

52. Dannemiller KC, Mendell MJ, Macher JM, Kumagai K, Bradman A, Holland N, et al. Next-generation DNA sequencing reveals that low fungal diversity in house dust is associated with childhood asthma development. Indoor Air. 2014;24(3):236-47. https://doi.org/10.1111/ina.12072.
53. Keating K. Statistical analysis of pyrosequence data. An abstract of a dissertation; 1977.

54. RStudio Team. RStudio: Integrated Development for R. [Internet]. RStudio, PBC. 2020 [cited 2020 Oct 17]. p. Boston, MA. Available from: https://rstudio. $\mathrm{com} /$

55. Pasanen AL, Juutinen T, Jantunen MJ, Kalliokoski P. Occurrence and moisture requirements of microbial growth in building materials. Int Biodeterior Biodegrad. 1992;30(4):273-83. https://doi.org/10.1016/0964-83 05(92)90033-K.

56. Haines SR, Adams RI, Boor BE, Bruton TA, Downey J, Ferro AR, et al. Ten questions concerning the implications of carpet on indoor chemistry and microbiology. Build Environ. 2020;170:106589.

57. Eggleston PA. Environmental control for fungal allergen exposure. Curr. Allergy Asthma Rep. 2003;3(5):424-9. https://doi.org/10.1007/s11882-0030079-5.

58. Gravesen S, Nielsen PA, Iversen R, Nielsen KF. Microfungal contamination of damp buildings - Examples of risk constructions and risk materials. Environ Health Perspect. 1999;107:505-8. https://doi.org/10.1289/ehp.99107s3505.

59. Chase J, Fouquier J, Zare M, Sonderegger DL, Knight R, Kelley ST, et al. Geography and location are the primary drivers of office microbiome composition. mSystems. 2016;1(2):e00022-16. https://doi.org/10.1128/ mSystems.00022-16.

60. Jayaprakash B, Adams RI, Kirjavainen P, Karvonen A, Vepsäläinen A, Valkonen $M$, et al. Indoor microbiota in severely moisture damaged homes and the impact of interventions. Microbiome. 2017;5(1):138. https://doi.org/10.1186/ s40168-017-0356-5.

61. Korpi A, Pasanen AL, Pasanen P, Kalliokoski P. Microbial growth and metabolism in house dust. Int Biodeterior Biodegrad. 1997;40(1):19-27. https://doi.org/10.1016/S0964-8305(97)00032-2.

62. Knudsen SM, Gunnarsen L, Madsen AM. Airborne fungal species associated with mouldy and non-mouldy buildings - effects of air change rates, humidity, and air velocity. Build Environ. 2017;122:161-70. https://doi.org/1 0.1016/j.buildenv.2017.06.017

63. Andersen B, Frisvad JC, Søndergaard I, Rasmussen IS, Larsen LS. Associations between fungal species and water-damaged building materials. Appl Environ Microbiol. 2011;77(12):4180-8. https://doi.org/10.1128/AEM.02513-1 0.

64. Nevalainen A, Seuri M. Of microbes and men. Indoor Air. 2005;15(s9):58-64. https://doi.org/10.1111/j.1600-0668.2005.00344.x.

65. Liu Z, Ye W, Little JC. Predicting emissions of volatile and semivolatile organic compounds from building materials: A review. Build. Environ. 2013; 64:7-25. https://doi.org/10.1016/j.buildenv.2013.02.012.

66. Bari MA, Kindzierski WB, Wheeler AJ, Héroux MĖ, Wallace LA. Source apportionment of indoor and outdoor volatile organic compounds at homes in Edmonton, Canada. Build Environ. 2015;90:114-24. https://doi. org/10.1016/j.buildenv.2015.03.023.

67. US EPA. CompTox Chemicals Dashboard [Internet]. CompTox Chem. Dashboard. 2020 [cited 2020 Nov 10]. Available from: https://comptox.epa gov/dashboard/dsstoxdb/results?search=DTXSID0026387\#exposure

68. Ohura T, Amagai T, Senga Y, Fusaya M. Organic air pollutants inside and outside residences in Shimizu, Japan: Levels, sources and risks. Sci Total Environ. 2006;366(2-3):485-99. https://doi.org/10.1016/j.scitotenv.2005.10.005

69. Lucattini L, Poma G, Covaci A, de Boer J, Lamoree MH, Leonards PEG. A review of semi-volatile organic compounds (SVOCs) in the indoor environment: occurrence in consumer products, indoor air and dust. Chemosphere. 2018; 201:466-82. https:/doi.org/10.1016/j.chemosphere.2018.02.161.

70. Wolkoff P, Wilkins CK. Indoor VOCs from household floor dust: comparison of headspace with Desorbed VOCs; method for VOC release determination. Indoor Air. 1994;4(4):248-54. https://doi.org/10.1111/j.1600-0668.1994.00005.x.

71. Schleibinger $H$, Keller R, Rüden H. Indoor Air Pollution by Microorganisms and Their Metabolites. In: Pluschke P. (eds) Air Pollution. Handb Environ Chem. 2004; 4. https://doi.org/10.1007/b94834.

72. Markowicz P, Larsson L. Influence of relative humidity on VOC concentrations in indoor air. Environ Sci Pollut Res. 2015:22(8):5772-9. https://doi.org/10.1007/s11356-014-3678-x.

73. ATSDR. Toxicological Profile for Phenol. ATSDR's Toxicol Profiles. 2002

74. Gu YQ, Mo MH, Zhou JP, Zou CS, Zhang KQ. Evaluation and identification of potential organic nematicidal volatiles from soil bacteria. Soil Biol Biochem. 2007;39(10):2567-75. https://doi.org/10.1016/j.soilbio.2007.05.011.

75. Pańka D, Piesik D, Jeske M, Baturo-Cieśniewska A. Production of phenolics and the emission of volatile organic compounds by perennial ryegrass 
(Lolium perenne L.)/Neotyphodium lolii association as a response to infection by Fusarium poae. J Plant Physiol. 2013;170:1010-9.

76. Fiedler K, Schütz E, Geh S. Detection of microbial volatile organic compounds (MVOCs) produced by moulds on various materials. Int J Hyg Environ Health. 2001;204(2-3):111-21. https://doi.org/10.1078/1438-463900094.

77. Bäck J, Aaltonen H, Hellén H, Kajos MK, Patokoski J, Taipale R, et al. Variable emissions of microbial volatile organic compounds (MVOCs) from rootassociated fungi isolated from Scots pine. Atmos Environ. 2010;44(30):36519. https://doi.org/10.1016/j.atmosenv.2010.06.042.

78. Weschler CJ, Hodgson AT, Wooley JD. Indoor chemistry: ozone, volatile organic compounds, and carpets. Environ Sci Technol. 1992;26(12):2371-7. https://doi.org/10.1021/es00036a006.

79. Wolkoff P, Wilkins CK, Clausen PA, Nielsen GD. Organic compounds in office environments - Sensory irritation, odor, measurements and the role of reactive chemistry. Indoor Air. 2006;16:7-19. https://doi.org/10.1111/j.16000668.2005.00393.x

80. Korpi A, Kasanen JP, Pasanen AL, Alarie Y, Kosma VM. Sensory Irritating Potency of Some Microbial Volatile Organic Compounds (MVOCs) and a Mixture of Five MVOCs. Arch Environ Health. 1999;54(5):347-52. https://doi. org/10.1080/00039899909602499.

81. Adams Rl, Bhangar S, Dannemiller KC, Eisen JA, Fierer N, Gilbert JA, et al. Ten questions concerning the microbiomes of buildings. Build Environ. 2016;109:224-34. https://doi.org/10.1016/j.buildenv.2016.09.001

82. Weschler CJ. Ozone in indoor environments: Concentration and chemistry. Indoor Air. 2000;10(4):269-88. https://doi.org/10.1034/j.1600-0668.2000.01 0004269.x.

83. Karlberg A-T, Magnusson K, Nilsson U. Air oxidation of d-limonene (the citrus solvent) creates potent allergens. Contact Dermatitis. 1992;26(5):33240. https://doi.org/10.1111/j.1600-0536.1992.tb00129.x.

84. Larsen FO, Norn S, Mordhorst CH, Stahl Skov P, Milman N, Clementsen P. Chlamydia pneumoniae and possible relationship to asthma: Serum immunoglobulins and histamine release in patients and controls. APMIS. 1998;106(7-12):928-34. https://doi.org/10.1111/j.1699-0463.1998.tb00241.x.

85. Bernstein JA, Alexis N, Bacchus H, Bernstein IL, Fritz P, Horner E, et al. The health effects of nonindustrial indoor air pollution. J Allergy Clin Immunol. 2008;121(3):585-91. https://doi.org/10.1016/j.jaci.2007.10.045

86. Claeson A. Volatile organic compounds from microorganisms: identification and health effects. Umeå. 2006;

87. Rădulescu Bouilly C, Allard F, Blondeau P, Collignan B, Popescu R, Sjoberg A. A physically- Based analysis of the interactions between humidity and VOCs in building materials. HB 2006 - Heal Build Creat a Heal Indoor Environ People, Proc. 2006

88. Haghighat F, De Bellis L. Material emission rates : Literature review, and the impact of indoor air temperature and relative humidity. Build Environ. 1998; 33(5):261-77. https://doi.org/10.1016/S0360-1323(97)00060-7.

89. Veres PR, Behrendt T, Klapthor A, Meixner FX, Williams J. Volatile Organic Compound emissions from soil: using Proton-Transfer-Reaction Time-ofFlight Mass Spectrometry (PTR-TOF-MS) for the real time observation of microbial processes. Biogeosciences Discuss. 2014;11:12009-38. https://doi. org/10.5194/bgd-11-12009-2014.

90. Infantino A, Costa C, Aragona M, Reverberi M, Taiti C, Mancuso S. Identification of different Fusarium spp. through mVOCS profiling by means of proton-transfer-reaction time-of-flight (PTR-TOF-MS) analysis. J Plant Pathol. Edizioni ETS. 2017;99:663-9. http://dx.doi.org/10.4454/jpp.v99i3.3953.

91. Mancuso S, Taiti C, Bazihizina N, Costa C, Menesatti P, Giagnoni L, et al. Soil volatile analysis by proton transfer reaction-time of flight mass spectrometry (PTR-TOF-MS). Appl Soil Ecol. 2015;86:182-91. https://doi.org/10.1016/j.a psoil.2014.10.018.

92. Lemfack MC, Gohlke BO, Toguem SMT, Preissner S, Piechulla B, Preissner R. MVOC 2.0: A database of microbial volatiles. Nucleic Acids Res. 2018;46(D1): D1261-5. https://doi.org/10.1093/nar/gkx1016.

93. Wilkins K, Larsen K, Simkus M. Volatile metabolites from mold growth on building materials and synthetic media. Chemosphere. 2000;41(3):437-46. https://doi.org/10.1016/S0045-6535(99)00273-8

\section{Publisher's Note}

Springer Nature remains neutral with regard to jurisdictional claims in published maps and institutional affiliations.

\section{Ready to submit your research? Choose BMC and benefit from:}

- fast, convenient online submission

- thorough peer review by experienced researchers in your field

- rapid publication on acceptance

- support for research data, including large and complex data types

- gold Open Access which fosters wider collaboration and increased citations

- maximum visibility for your research: over $100 \mathrm{M}$ website views per year

At BMC, research is always in progress.

Learn more biomedcentral.com/submissions 